\title{
Upper Cretaceous intrusives in the Coastal Cordillera near Valdivia: forearc magmatism related to the passage of a triple junction?
}

\author{
Denisse de la Fuente ${ }^{1}$ * Óscar Figueroa ${ }^{1}$, Daniel Demaiffe ${ }^{2}$, Mauricio Mella ${ }^{3}$, \\ Paul Duhart ${ }^{3}$, David Quiroz ${ }^{3}$, Jorge Muñoz ${ }^{4}$, Verónica Oliveros ${ }^{1}$
}

\author{
1 Departamento Ciencias de la Tierra, Universidad de Concepción, Casilla 160-C, Concepción, Chile. \\ denissdelafuent@covalente.cl; oerfiga@udec.cl; voliveros@udec.cl \\ 2 Université Libre de Bruxelles (ULB), DGES (CP 160/02), Laboratoire de Géochimie, 50 Av. F. D. Roosevelt, B-1050 Bruxelles, Belgium. \\ ddemaif@ulb.ac.be \\ 3 Oficina Técnica Puerto Varas, Sernageomin, La Paz 406, Puerto Varas, Chile. \\ mauricio.mella@sernageomin.cl; paul.duhart@sernageomin.cl; david.quiroz@sernageomin.cl \\ 4 Sernageomin, Santa María 0104, Santiago, Chile. \\ jorge.munoz@sernageomin.cl \\ * Corresponding author: oerfiga@udec.cl
}

\begin{abstract}
Upper Cretaceous intrusives of limited extent crop out in the Coastal Cordillera near of Valdivia (3948' S), $100 \mathrm{~km}$ west of the main topographic divide of the Andean Cordillera. Given that plutonic rocks of the same age crop out at the same latitudes in the high Andes the coastal intrusives emplaced in a forearc position in the upper plate of a subduction setting. They correspond to hypabyssal intrusives displaying mainly porphyritic texture and lithological variations with microtonalites (minor), porphyritic microgranodiorites (main) and microgranites. They intrude the Upper Paleozoic-Triassic accretionary complex of the Bahia Mansa Metamorphic Complex. These intrusives, that comprise the Chaihuín Pluton and minor stocks of porphyritic felsic rocks, have calc-alkaline affinities with metaluminous and peraluminous character. They are geochemically similar to the contemporaneous main arc-related plutonic rocks of the Gualletué Plutonic Group. The microgranitoids and dacitic rocks from Los Boldos, the low and Loncoche are peculiar because they show an apparently adakitic affinity in $\mathrm{Sr} / \mathrm{Y}$ and $\mathrm{La}_{\mathrm{N}} / \mathrm{Yb}_{\mathrm{N}}$ discriminant diagrams; nevertheless $\mathrm{Sr}$ contents of these rocks $(<<400 \mathrm{ppm})$ preclude a true adakitic character. The petrogenesis of the Chaihuín Pluton, is consistent with an evolution from tonalite to granite by successive fractional crystallization of plagioclase, amphibole, biotite, Fe-Ti oxides, apatite and zircon. The initial ${ }^{87} \mathrm{Sr} r{ }^{86} \mathrm{Sr}$ ratio $(0.70411-0.70745), \varepsilon N d(+4.24$ to -3.09$)$ and present-day $\mathrm{Pb}$ isotopic ratios ( ${ }^{206} \mathrm{~Pb} / 204 \mathrm{~Pb}$ : 18.616 to $18.708 ;{ }^{207} \mathrm{~Pb} /{ }^{204} \mathrm{~Pb}$ : 15.620 to $15.635 ;{ }^{208} \mathrm{~Pb} /{ }^{204} \mathrm{~Pb}$ : 38.573 to 38.662 ) of these rocks indicate that depleted mantle derived-magmas were contaminated by assimilation of crustal material at the base of the paleo accretionary prism or by subduction erosion. The heat required to explain mantle melting beneath the forearc crust could be supplied by the subduction of a young and hot oceanic slab and/or an active spreading ridge, as attested in similar settings in the world. According to plate reconstruction models the studied forearc intrusives would be generated during the migration of a triple junction that passed near Valdivia between 100 and 70 Ma.
\end{abstract}

Keywords: Valdivia, Forearc Intrusives, Petrography and Geochemistry, Isotopes, Ridge Subduction. 
RESUMEN. Intrusivos Cretácico Superior en la Cordillera de la Costa del área de Valdivia: magmatismo de antearco relacionado al paso de un punto triple?. En la costa cerca de Valdivia (3948’ S) afloran intrusivos del Cretácico Superior de limitada extensión. En consideración a que a la misma latitud en la Cordillera de Los Andes hay rocas plutónicas de la misma edad emplazadas en un ambiente de arco magmático, estos intrusivos de la costa se disponen en un ambiente tectónico de antearco. Ellos corresponden a intrusivos someros, de textura principalmente porfídica y que varían de microtonalitas (escasas) a microgranodioritas porfídicas (mayor ocurrencia) y a microgranitos. Ellos intruyen a las rocas del prisma acrecionario Paleozoico superior-Triásico agrupadas en el Complejo Metamórfico Bahía Mansa. De norte a sur, los intrusivos estudiados corresponden a: Granitoide Los Boldos, Pórfido dacítico Loncoche, Pórfido Oncol, Pórfido dacítico Laurel y Plutón Chaihuín. Este último es el de mayor extensión (24km) y de mayor variación composicional (tonalita a granito). Estos intrusivos tienen una afinidad calcoalcalina, con un carácter metaluminoso a peraluminoso. Desde el punto de vista geoquímico, son similares a las rocas contemporáneas del arco principal, representado por el Grupo Plutónico Gualletué (3845’ S, $72^{\circ} 30^{\prime}$ W). Los intrusivos de Los Boldos y Loncoche son particulares ya que presentan una afinidad aparentamente adakítica en los diagramas discriminantes $\mathrm{Sr} / \mathrm{Y} \mathrm{y} \mathrm{La}_{\mathrm{N}} / \mathrm{Yb}_{\mathrm{N}}$; sin embargo los bajos contenidos en $\mathrm{Sr}$ de estas rocas $(<<400 \mathrm{ppm})$ no son compatible con el carácter adakítico. La petrogénesis del Plutón Chaihuín es consistente con una evolución de tonalita a granito, por cristalización fraccionada de plagioclasa, anfíbol, biotita, óxidos de Fe-Ti, apatito y zircón. Las razones iniciales de ${ }^{87} \mathrm{Sr} /{ }^{86} \mathrm{Sr}(0.70411-0.70745)$, عNd (4.24 a -3.09) y las razones isotópicas actuales de $\mathrm{Pb}\left({ }^{206} \mathrm{~Pb} /{ }^{204} \mathrm{~Pb}: 18.616\right.$ a $18.708 ;{ }^{207} \mathrm{~Pb} / 204 \mathrm{~Pb}: 15.620$ a 15.635 ; ${ }^{208} \mathrm{~Pb} /{ }^{204} \mathrm{~Pb}$ : 38.573 a 38.662) de estas rocas, indican que magmas deprimidos originados en el manto fueron contaminados por asimilación de material cortical del prisma acrecionario Paleozoico superior-Triásico. El calor requerido para explicar la fusión del manto ubicado debajo del antearco pudo haber provenido de la subducción de una dorsal joven y caliente, como ocurrió en ambientes similares de otras partes del mundo. De acuerdo con los modelos de reconstrucción de las placas tectónicas los intrusivos del área de Valdivia se habrían generado por la subducción de una dorsal activa que afectó el área de Valdivia entre los 100 y 70 Ma.

Palabras clave: Valdivia, Intrusivos de Antearco, Petrografía y Geoquímica, Isótopos, Subducción de Dorsal.

\section{Introduction}

In the Coastal Range of South Central Chile, between $39^{\circ} \mathrm{S}$ and $40^{\circ} \mathrm{S}$, outcrops of isolated intrusive bodies of limited extension ( $<$ to $24 \mathrm{~km}$ long) and of Upper Cretaceous age (mainly 92-83 Ma; Table 1) have been identified. At that time and at same latitudes, the corresponding subduction-related magmatic arc was approximately $100 \mathrm{~km}$ to the east, in the present Main Andean Cordillera position (Fig. 1, Table1). The existence of such magmatic rocks in the Coastal Range represent magmatic suites emplaced in the forearc crust which is typically a nonmagmatic zone with low heat flow (Gill, 1981). However, occurrences of magmatic activity in forearc positions have been reported recently elsewhere in the world. Examples of this magmatism comprises the semicontinuous igneous belts that extends from Alaska to Oregon (e.g., Madsen et al., 2006; Ayuso et al., 2009) and the Taitao granite intrusions related to the subduction of the active Chile ridge beneath the Taitao Peninsula in southern Chile (e.g., Forsythe et al., 1986; Guivel et al., 2003; Anma et al., 2009).

Cases of forearc magmatism have been attributed to the subduction of mid-ocean ridges, which confers an additional thermal input to this area (e.g., Marshak and Karig, 1977; DeLong et al., 1979; Sisson et al., 2003). Several other forearc occurrences have been reported and are explained by various processes: 1) the Coastal Oligocene-Miocene Magmatic Belt of Central Southern Chile (Muñoz et al., 2000, 2007) has been related to an increase in the convergence rate in the Oligocene-Miocene and the subsequent roll-back of the convergent margin; 2) the forearc lavas from Las Pataguas, Central Chile, related to the slowing of convergence acceleration at the end of the extensional regime during the Miocene (Wall and Lara, 2001); and 3) the minor dacites and tuffs of The Llano de Chocolate Beds from Late Paleozoic forearc of north Chile (28 $30^{\circ}-29^{\circ} 30^{\prime}$ S), whose origin can be related to the high thermal gradient due to the onset of the subduction system (Creixell et al., 2016).

In a regional study, Glodny et al. (2006) suggested that the origin of the intrusives in the coast of the study area would be related to the passage of the triple junction formed by the Farallon-Aluk (Phoenix)South America plates. Based on zircon and apatite fission track studies, Glodny et al. (2007) also suggested that Toltén and Chiloé forearc zone would have experienced a transient heating in the Upper Cretaceous. This would suggest that the geographical 
TABLE 1. PUBLISHED RADIOMETRIC AGES OF THE UPPER CRETACEOUS INTRUSIVES LOCATED IN COASTAL AND ANDES RANGES, CORRESPONDING TO THE FOREARC AND ARC AREAS, RESPECTIVELY.

\begin{tabular}{|c|c|c|c|c|c|c|c|c|}
\hline & Unit & Sample & $\mathbf{N}$ & $\mathbf{E}$ & Rock & Age (Ma) & Method & Reference \\
\hline \multirow{15}{*}{ 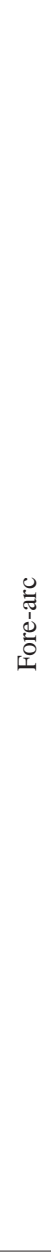 } & Los Boldos & Bol 1 & *up & *up & granodiorite & $86 \pm 3$ & K-Ar biotite & $\begin{array}{c}\text { Munizaga et al., } \\
1988\end{array}$ \\
\hline & Los Boldos & XI-1347 & $39^{\circ} 13^{\prime} 52^{\prime \prime}$ & $72^{\circ} 54^{\prime} 16^{\prime \prime}$ & granodiorite & $89 \pm 2$ & K-Ar biotite & $\begin{array}{l}\text { Quiroz et al., } \\
2007\end{array}$ \\
\hline & Loncoche & XI-1245 & $39^{\circ} 19^{\prime} 38^{\prime \prime}$ & $72^{\circ} 34^{\prime} 12^{\prime \prime}$ & $\begin{array}{l}\text { riodacitic } \\
\text { porphyry }\end{array}$ & $72 \pm 2$ & K-Ar biotite & $\begin{array}{l}\text { Quiroz et al., } \\
2007\end{array}$ \\
\hline & Loncoche & XI-1255 & $39^{\circ} 17^{\prime} 54^{\prime \prime}$ & $72^{\circ} 34^{\prime} 21^{\prime \prime}$ & $\begin{array}{l}\text { riodacitic } \\
\text { porphyry }\end{array}$ & $87 \pm 2$ & K-Ar biotite & $\begin{array}{l}\text { Quiroz et al., } \\
2007\end{array}$ \\
\hline & Oncol & XK0311 & $39^{\circ} 41^{\prime} 34^{\prime \prime}$ & $73^{\circ} 20^{\prime} 40^{\prime \prime}$ & granodiorite & $91 \pm 2$ & K-Ar biotite & $\begin{array}{c}\text { SERNAGEOMIN, } \\
1998\end{array}$ \\
\hline & Laurel & $\begin{array}{l}\text { RMMR- } \\
026\end{array}$ & $39^{\circ} 50^{\prime} 36^{\prime \prime}$ & $73^{\circ} 09^{\prime} 55^{\prime \prime}$ & dacite & $80.5 \pm 0.1$ & $\begin{array}{l}{ }^{40} \mathrm{Ar} /{ }^{39} \mathrm{Ar} \\
\text { groundmass }\end{array}$ & $\begin{array}{l}\text { Mella et al., } \\
\quad 2012\end{array}$ \\
\hline & Chaihuín & CHAI1 & $39^{\circ} 56^{\prime} 09^{\prime \prime}$ & $73^{\circ} 35^{\prime} 41^{\prime \prime}$ & granodiorite & $103 \pm 2$ & K-Ar biotite & $\begin{array}{c}\text { Munizaga et al., } \\
1988\end{array}$ \\
\hline & Chaihuín & *up & $39^{\circ} 53^{\prime} 58^{\prime \prime}$ & $73^{\circ} 29^{\prime} 51^{\prime \prime}$ & granodiorite & $85.8 \pm 1$ & $\mathrm{U}-\mathrm{Pb}$ & Martin, 1996 \\
\hline & Chaihuín & XO0020 & $39^{\circ} 54^{\prime} 10^{\prime \prime}$ & $73^{\circ} 30^{\prime} 00^{\prime \prime}$ & granodiorite & $92 \pm 2$ & K-Ar biotite & $\begin{array}{c}\text { Duhart et al., } \\
1997\end{array}$ \\
\hline & Chaihuín & XO-20 & $39^{\circ} 53^{\prime} 58^{\prime \prime}$ & $73^{\circ} 29^{\prime} 51^{\prime \prime}$ & granitic dike & $91.3 \pm 4.9$ & U-Pb zircon & $\begin{array}{c}\text { Martin et al., } \\
1999\end{array}$ \\
\hline & Chaihuín & XO0020 & $39^{\circ} 54^{\prime} 10^{\prime \prime}$ & $73^{\circ} 30^{\prime} 00^{\prime \prime}$ & granodiorite & $85.8 \pm 1$ & U-Pb zircon & $\begin{array}{c}\text { Duhart et al., } \\
2001\end{array}$ \\
\hline & Chaihuín & $\begin{array}{c}\text { RMMR- } \\
013\end{array}$ & $39^{\circ} 54^{\prime} 05^{\prime \prime}$ & $73^{\circ} 29^{\prime} 56^{\prime \prime}$ & diorite & $78 \pm 3$ & $\begin{array}{l}\text { K-Ar whole } \\
\text { rock }\end{array}$ & $\begin{array}{l}\text { Mella et al., } \\
\quad 2012\end{array}$ \\
\hline & Chaihuín & $\begin{array}{c}\text { RMMR- } \\
019\end{array}$ & $39^{\circ} 57^{\prime} 30^{\prime \prime}$ & $73^{\circ} 36^{\prime} 10^{\prime \prime}$ & granodiorite & $87.8 \pm 0.2$ & $\begin{array}{l}{ }^{40} \mathrm{Ar} /{ }^{39} \mathrm{Ar} \\
\text { biotite }\end{array}$ & $\begin{array}{l}\text { Mella et al., } \\
\quad 2012\end{array}$ \\
\hline & Chaihuín & $\begin{array}{c}\text { RMMR- } \\
012\end{array}$ & $39^{\circ} 54^{\prime} 02^{\prime \prime}$ & $73^{\circ} 29^{\prime} 52^{\prime \prime}$ & granodiorite & $92 \pm 2$ & K-Ar biotite & $\begin{array}{l}\text { Mella et al., } \\
\quad 2012\end{array}$ \\
\hline & Chaihuín & $\begin{array}{l}\text { RMMR- } \\
023\end{array}$ & $39^{\circ} 57^{\prime} 40^{\prime \prime}$ & $73^{\circ} 34^{\prime} 25^{\prime \prime}$ & granite & $88.8 \pm 0.2$ & $\begin{array}{l}{ }^{40} \mathrm{Ar} /{ }^{39} \mathrm{Ar} \\
\text { biotite }\end{array}$ & $\begin{array}{l}\text { Mella et al., } \\
\quad 2012\end{array}$ \\
\hline \multirow{7}{*}{ 远 } & Gualletué & $\mathrm{J}-31$ & $38^{\circ} 35^{\prime} 51^{\prime \prime}$ & $71^{\circ} 26^{\prime} 03^{\prime \prime}$ & tonalite & $82.7 \pm 2$ & K-Ar biotite & $\begin{array}{c}\text { IIG/MMAJ/JICA } \\
\text { (1978) }\end{array}$ \\
\hline & Gualletué & K-81 & $38^{\circ} 40^{\prime} 08^{\prime \prime}$ & $71^{\circ} 21^{\prime} 53^{\prime \prime}$ & granodiorite & $93.6 \pm 5$ & K-Ar biotite & $\begin{array}{c}\text { IIG/MMAJ/JICA } \\
\text { (1978) }\end{array}$ \\
\hline & Gualletué & IGE-6 & $38^{\circ} 48^{\prime} 29^{\prime \prime}$ & $71^{\circ} 16^{\prime} 28^{\prime \prime}$ & granodiorite & $86 \pm 4$ & $\begin{array}{c}\text { K-Ar } \\
\text { amphibole }\end{array}$ & $\begin{array}{c}\text { Suárez et al., } \\
1986\end{array}$ \\
\hline & Reigolil & XC-188 & $39^{\circ} 04^{\prime} 32^{\prime \prime}$ & $71^{\circ} 29^{\prime} 42^{\prime \prime}$ & granodiorite & $84 \pm 2$ & K-Ar biotite & $\begin{array}{l}\text { Moreno y Lara, } \\
2008\end{array}$ \\
\hline & Caburga & XG-220 & $39^{\circ} 05^{\prime} 21^{\prime \prime}$ & $71^{\circ} 48^{\prime} 51^{\prime \prime}$ & granite & $79 \pm 2$ & K-Ar biotite & $\begin{array}{l}\text { Moreno y Lara, } \\
2008\end{array}$ \\
\hline & Paimún & PUC10 & $39^{\circ} 33^{\prime} 09^{\prime \prime}$ & 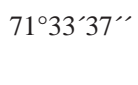 & tonalite & $94 \pm 2$ & K-Ar biotite & $\begin{array}{c}\text { Munizaga et al., } \\
1988\end{array}$ \\
\hline & Paimún & XG-196 & $39^{\circ} 41^{\prime} 23^{\prime \prime}$ & $71^{\circ} 42^{\prime} 24^{\prime \prime}$ & granodiorite & $92 \pm 3$ & $\begin{array}{c}\mathrm{K}-\mathrm{Ar} \\
\text { amphibole }\end{array}$ & $\begin{array}{l}\text { Lara y Moreno, } \\
2004\end{array}$ \\
\hline
\end{tabular}

*up: unpublished data. 


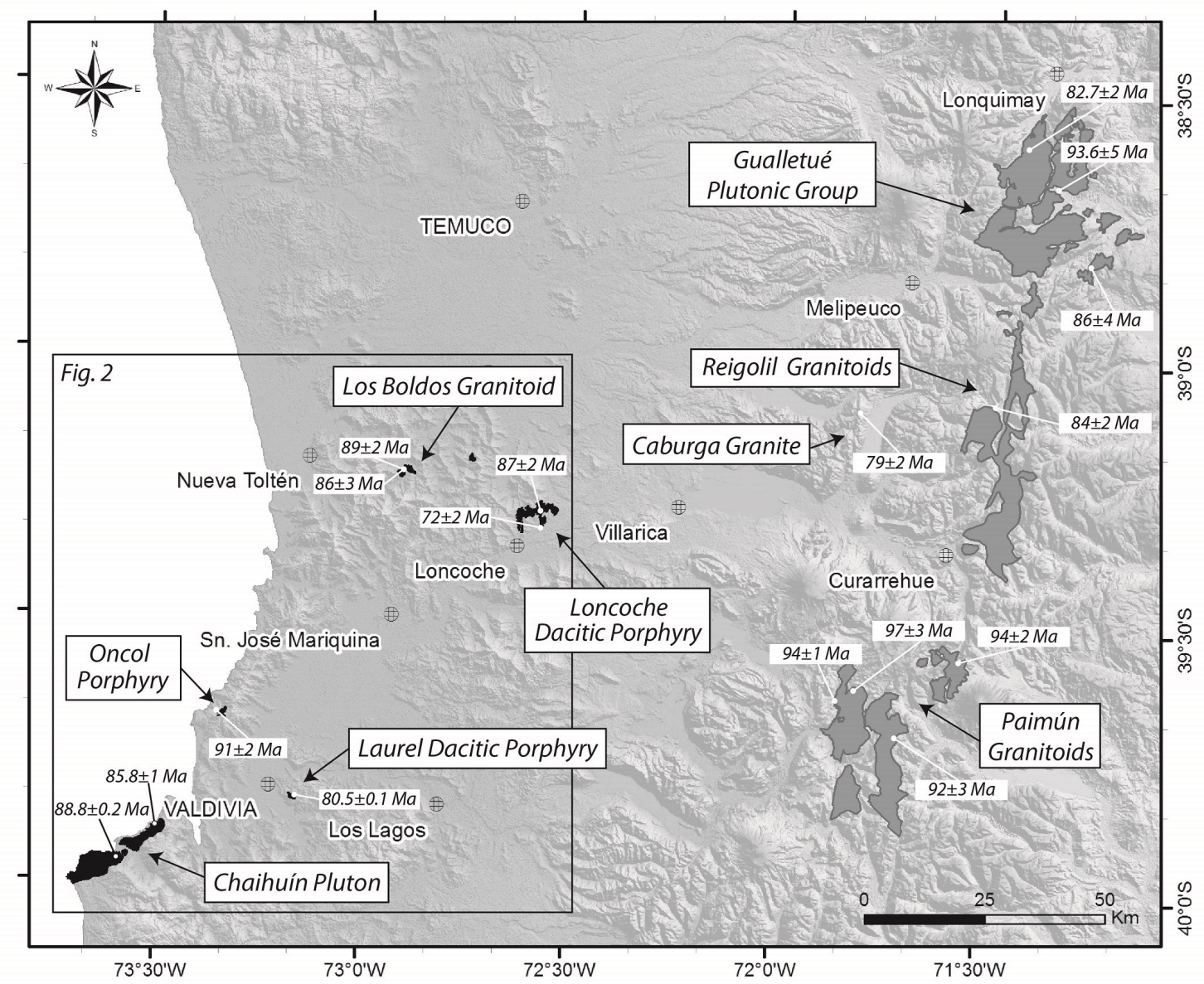

FIG. 1. Location of Upper Cretaceous forearc intrusives (black) together with contemporary arc plutons emplaced in the Principal Cordillera (gray), between latitudes $38^{\circ} 30^{\prime} \mathrm{S}$ and $40^{\circ} \mathrm{S}$, indicating their age (more details in Table 1 ). The study area (box) is magnified in figure 2. Gualletué Plutonic Group (Suárez and Emparan, 1997) is indicated in the Principal Cordillera from which samples were taken for comparison. In addition, Caburga Granite and Reigolil Granitoids (Moreno and Lara, 2008), and Paimun Granitoid (Lara and Moreno, 2004) are also indicated. Based on the Chilean Geological Map 1:1.000.000 (Digital version, Sernageomin, 2004).

extension of the forearc magmatism could be larger than the limited intrusives described in this paper.

This work presents new field, petrographic, geochemical and isotopic data on the forearc intrusives of the Valdivia area, in order to clarify their petrogenesis and shed new information on the potential effects of Upper Cretaceous ridge subduction at these latitudes.

\section{Regional geological framework}

In the Coastal Range of the Valdivia area (Fig. 2), Paleozoic-Triassic metamorphic rocks belonging to the Western Series of the Metamorphic Basement dominate (Aguirre et al., 1972; Hervé; 1988, Willner, 2005). At these latitudes the Western Series are known as Bahía Mansa Metamorphic Complex (BMMC; Duhart et al., 2001). The BMMC consists of pelitic to semipelitic schists with subordinate mafic schists and ultramafic rocks (Duhart et al., 2001; Quiroz et al., 2007), which represent an accretionary system associated to subduction processes between Upper Paleozoic and Triassic times, in the southwestern edge of Gondwanaland (Duhart et al., 2001; Glodny et al., 2005; Hervé et al., 2013).

In the study area, the BMMC is locally intruded by small shallow-level granitoids and dacitic porphyries of Upper Cretaceous age (Table 1). In general, these 


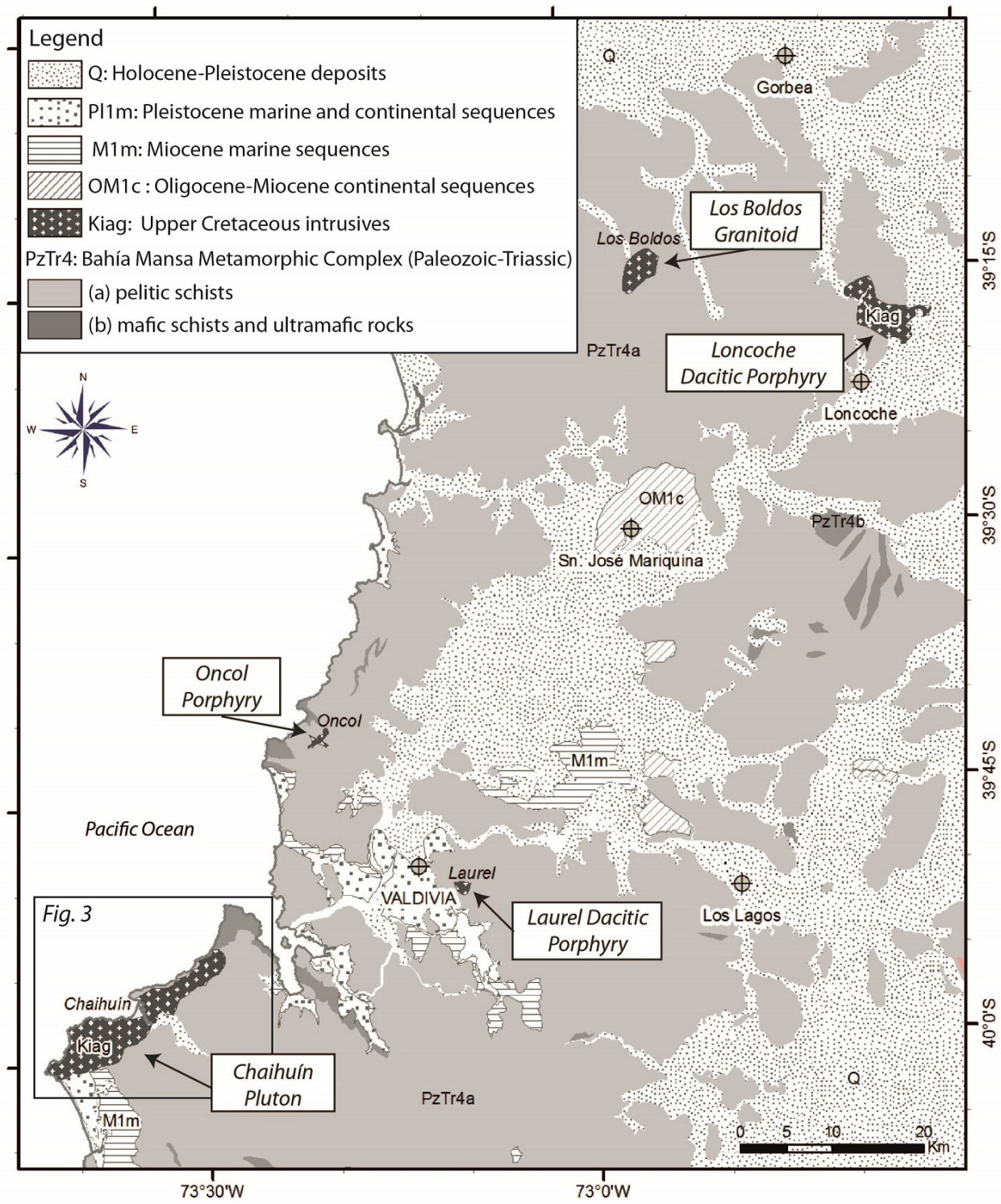

FIG. 2. Geological map of the studied area indicating the name of the intrusions of interest. Q (Holocene-Pleistocene): Fluvial, coastal, glacigenic and landslides deposits. Pl1m (Pleistocene): Marine coastal or fluvial sedimentary sequences. M1m (Miocene): transgressive marine sedimentary sequences. OM1c (Oligocene-Miocene): alluvial or paralical continental sedimentary sequences. Kiag (Upper Cretaceous): granitoids and dacitic porphyries. PzTr4 (Paleozoic-Triassic): Bahía Mansa Metamorphic Complex, (a) pelitic schists, (b) mafic schists and ultramafic rocks. Based on the Chilean Geological Map (Digital version, Sernageomin, 2004). Detailed geology of Chaihuín Pluton is magnified in figure 3.

plutonic to subvolcanic rocks are strongly altered and weathered, exhibiting spheroidal weathering with less altered cores of up to $1 \mathrm{~m}$ in diameter. In addition, there are numerous mafic and felsic dikes intruding the host rocks near the intrusives. The localities were these intrusions crop out are (Fig. 2):
- Chaihuín Pluton (Arenas et al., 2005): corresponds to one NE-SW elongated intrusion which has the greatest extension (24 km long; Fig. 3). It is mostly composed of porphyritic microgranodiorites that are intruded by the Pan de Azúcar Granite in its central part (Mella et al., 2012). Contacts 


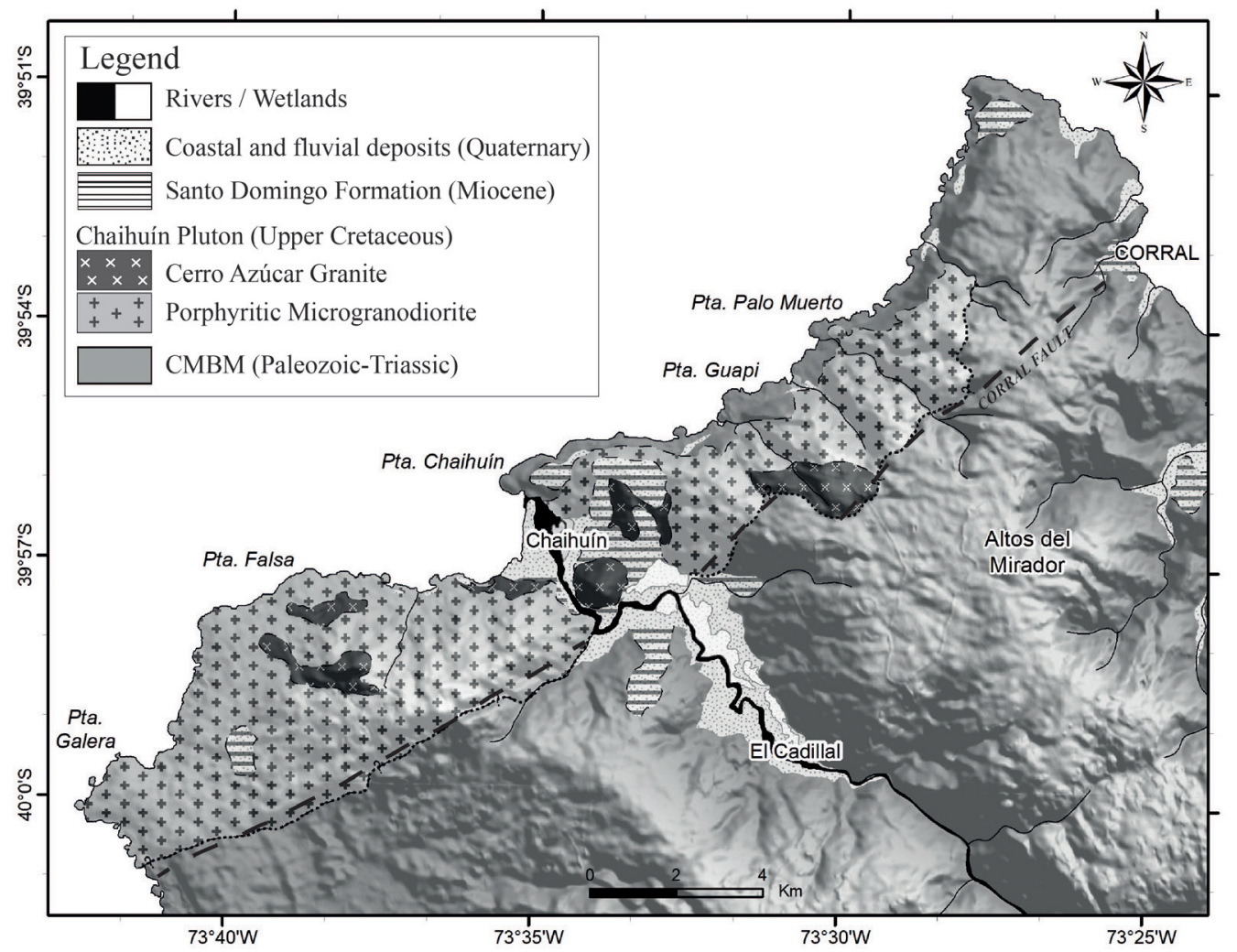

FIG. 3. Geological map of Chaihuín Pluton (scale 1:125,000) produced by using digital elevation model (DEM). Eastern edge contact of Chaihuín Pluton is inferred (dashed line) as well as most of the microgranite limits. Corral Fault (NE-SW) is indicated by coarse dashed line. Modified from Mella et al. (2012).

of the pluton with BMMC are by intrusion (Sernageomin, 1998) but in its northern edge (Fig. 3), it is a faulted contact (the Corral Fault; Mella et al., 2012).

- Los Boldos Granitoids (Munizaga et al., 1988): corresponds to two small intrusions $(<2 \mathrm{~km}$, each in lateral extend) that are locally strongly weathered and have whitish aspect.

- Loncoche dacitic porphyries: corresponds to two bodies (1 and 9 km long) of porphyritic felsic rocks, with whitish aspect. Their shape is like a laccolith with dip to the south (Quiroz et al., 2007).

- Oncol dacitic porphyry: corresponds to a strongly weathered intrusive body with spheroidal relicts.

- Laurel dacitic porphyry: corresponds to one intrusion (2 km long) (Arenas et al., 2005; Mella et al., 2012) with spheroidal relicts.

The above mentioned intrusives are partially covered by the Pupunahue Strata (Oligocene-Miocene; Illies, 1970) of continental origin, Santo Domingo
Formation (Lower to Middle Miocene; Martínez and Pino, 1979; Mella et al., 2012) of marine nature, and by glacial, fluvial and coastal Quaternary deposits (Arenas et al., 2005; Quiroz et al., 2007).

These coastal intrusives will be compared with the Gualletué Plutonic Group, which is a belt of plutonic rocks in the Andean Cordillera, south of Lonquimay (Fig. 1). This plutonic Group is composed of different intrusions from Upper Jurassic to Upper Cretaceous, in at least 3 subunits of 148-140, 126 and 108-73 Ma (Suárez and Emparán, 1997; Table 1).

\section{Petrography}

The studied fine-grained hypabyssal rocks vary from tonalite to granite, and display mostly porphyritic texture. Lithological variations in the five studied intrusive complexes (Fig. 4) are as follows:

- Chaihuín Pluton: porphyritic microgranodiorites, microgranites \pm microtonalites. 


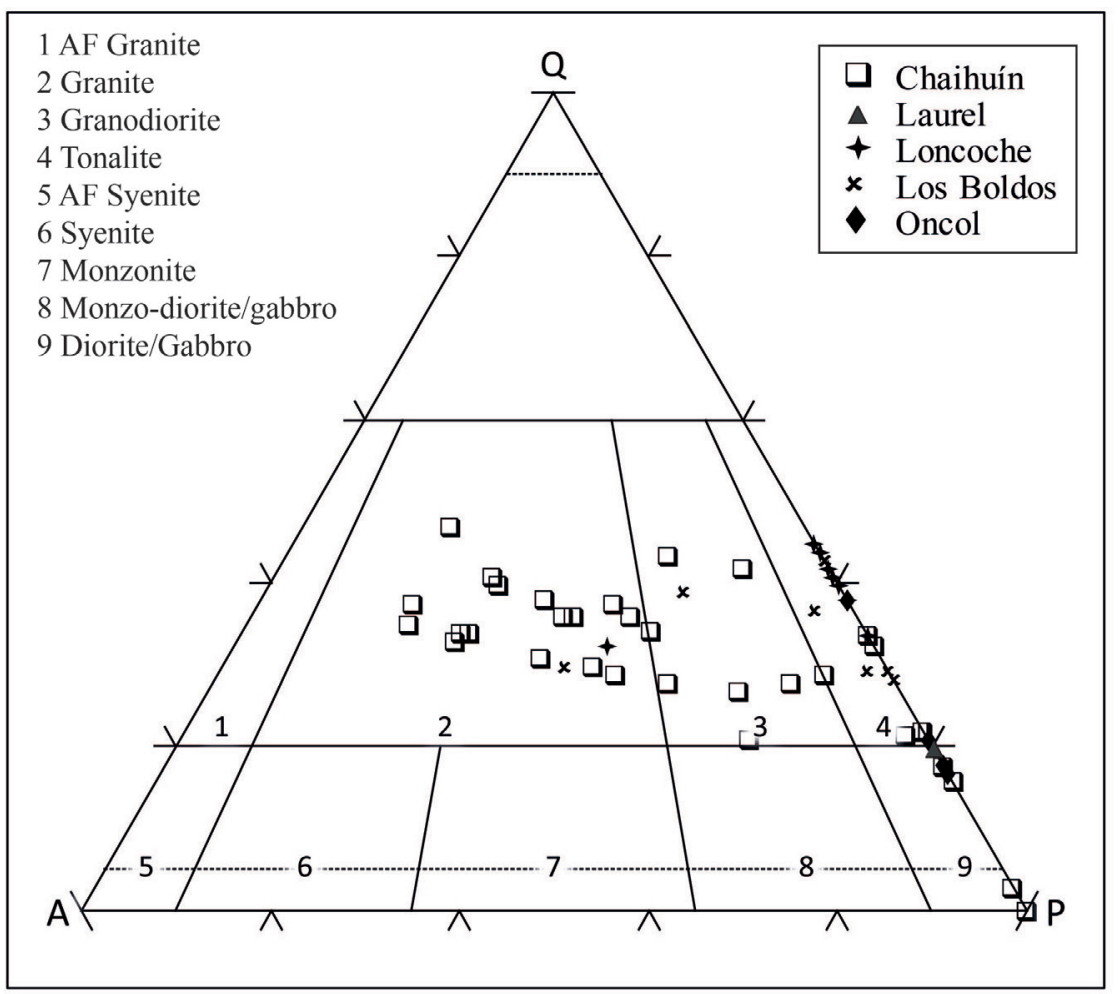

FIG. 4. QAP petrographic classification diagram (Streckeisen, 1976) of the forearc intrusives. Q: quartz, A: alkaline feldspar, P: plagioclase, AF: Alkali Feldespar.

- Los Boldos granitoid: microtonalites, microgranodiorites and microgranites.

- Oncol: dacitic and minor andesitic porphyries.

- Loncoche: dacitic porphyry.

- Laurel: dacitic porphyry.

The Chaihuín Pluton shows the greatest exposed area, contains microdiorite enclaves (Fig. 5A) and is predominantly formed by porphyritic biotite and biotite-amphibole microgranodiorites (Fig. 6A). Its central part consists of biotite microgranites (Pan de Azúcar Granite, Fig. 6B) and its southwestern edge (Punta Galera) of tonalites. Microgranodiorites are made of andesine (25-50\%), quartz (20-30\%), generally perthitic orthoclase (10-15\%), amphibole (2-5\%) and biotite (4-10\%). The phenocrysts (20\%) are mainly plagioclase of variable size, up to $1 \mathrm{~cm}$ long. The groundmass is fine-grained $(<1 \mathrm{~mm})$ and hypidiomorphic granular. The tonalites are quite similar to microgranodiorites. The microgranites exhibit hypidiomorphic granular texture; they are fine- to medium-grained $(0.1-1.5 \mathrm{~mm})$ with some larger crystals (5 mm), providing locally a porphyritic texture. They are composed of quartz (27-34\%), orthoclase (22-43\%), oligoclase (22-40\%), biotite and amphibole (2-4\%). Intergrowth textures (micrographic and granophyric) between quartz and alkali feldspar are locally observed. In both lithologies plagioclase shows compositional zonation $\left(\mathrm{An}_{40-28}\right.$ in microgranodiorite; $\mathrm{An}_{32-21}$ in some phenocrysts of microgranite), with moderate alteration to sericite and clay minerals. Minor and accessory minerals are titanite, apatite, zircon, very fine opaque minerals and secondary epidote. In the western edge of the intrusion, numerous miarolitic cavities up to $40 \mathrm{~cm}$ in diameter are found; cm large crystals of quartz and alkali feldspar fill them.

The Chaihuín mafic enclaves (up to $1 \mathrm{~m}$; Fig. 5A) have ellipsoidal shapes with both sharp and diffuse edges contacts. Their composition corresponds to an amphibole microdiorite; locally, it contains secondary quartz and orthoclase. They show microgranular to porphyritic textures (Fig. 6C). They are comparable 

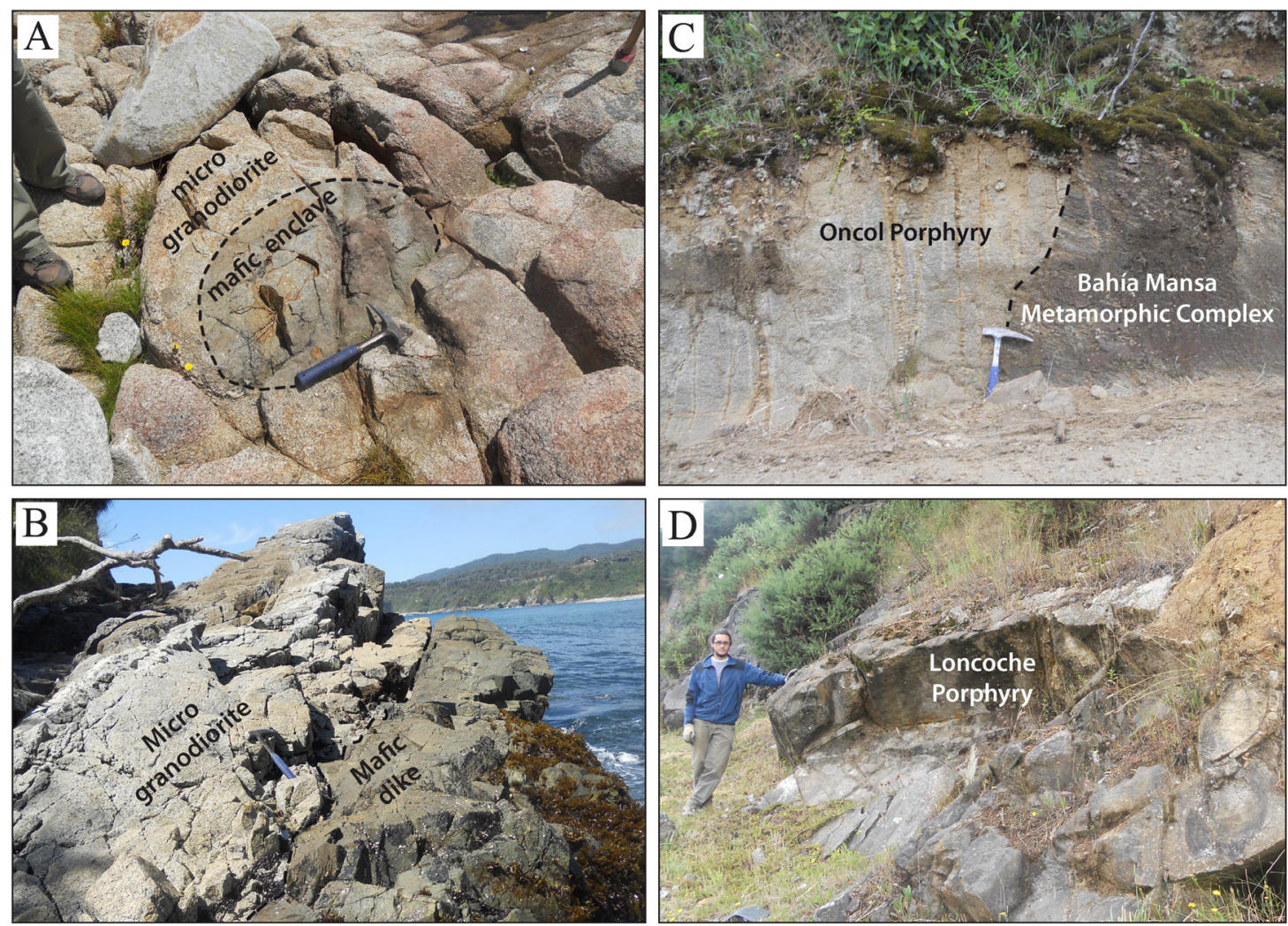

FIG. 5. Outcrop photographs of some of studied forearc intrusions: western edge of the Chainuín Pluton, showing one of the microdioritic enclaves included in this intrusive (A), and an andesitic dike intruding the granodioritic rocks (B). Contact between Oncol Porphyry and Bahía Mansa Metamorphic Complex, near the Parque Oncol (C). Loncoche dacitic porphyry outcropping in the northeast part of the Cerro Niquén (D).

to the mafic microgranular enclaves described by Barbarin and Didier (1992) in many plutonic complexes worldwide. Some enclaves are surrounded by felsic reaction haloes indicating assimilation. The more mafic enclaves (e.g., Ch-A2) correspond to microdiorite with a slightly porphyritic texture: altered plagioclase $\left(\mathrm{An}_{26}, 9 \%\right)$ and amphibole (3\%) phenocrysts are dispersed in a fine-grained hypidiomorphic granular groundmass, composed of plagioclase (80\%), amphibole (5\%), chloritized biotite (3\%), titanite and secondary quartz distributed in irregular concentrations or as fine veinlets in the rock. The Chaihuín Pluton also contains numerous partially digested xenoliths of metamorphic rocks. These xenoliths are foliated and composed of white mica, quartz, albite \pm biotite and magnetite.

The rocks of the Los Boldos Granitoids are medium-to fine-grained (up to $1.5 \mathrm{~mm}$ ) with granular to slightly porphyritic textures (plagioclase phenocrysts up to $3.5 \mathrm{~mm}$ ). Their compositions vary from tonalite to granodiorite. Locally, the pluton is dynamically recrystallized. The tonalite is composed of plagioclase $\left(\mathrm{An}_{35}, 53-60 \%\right)$, quartz (26-40\%), biotite (7-12\%), orthoclase $(<2 \%)$ and fine opaque minerals $(<1 \%)$, while the microgranodiorite contains plagioclase (35\%), orthoclase (15\%), quartz (40\%), biotite (10\%) and accessory opaque minerals $(<1 \%)$.

The intrusions of Oncol (Fig. 5C), Loncoche (Fig. 5D) and Laurel are dacitic porphyries; the phenocrysts (up to $5 \mathrm{~mm}$ ) are dispersed in a microgranular or rarely felsitic $(<0.2 \mathrm{~mm})$ groundmass. The main phenocrysts are plagioclase (20-35\%), quartz (1-5\%), biotite (3-8\%) and amphibole $(<6 \%)$. Quartz crystals tend to form sinuous edges and embayments; the plagioclases locally constitute glomeroporphyritic aggregates. 

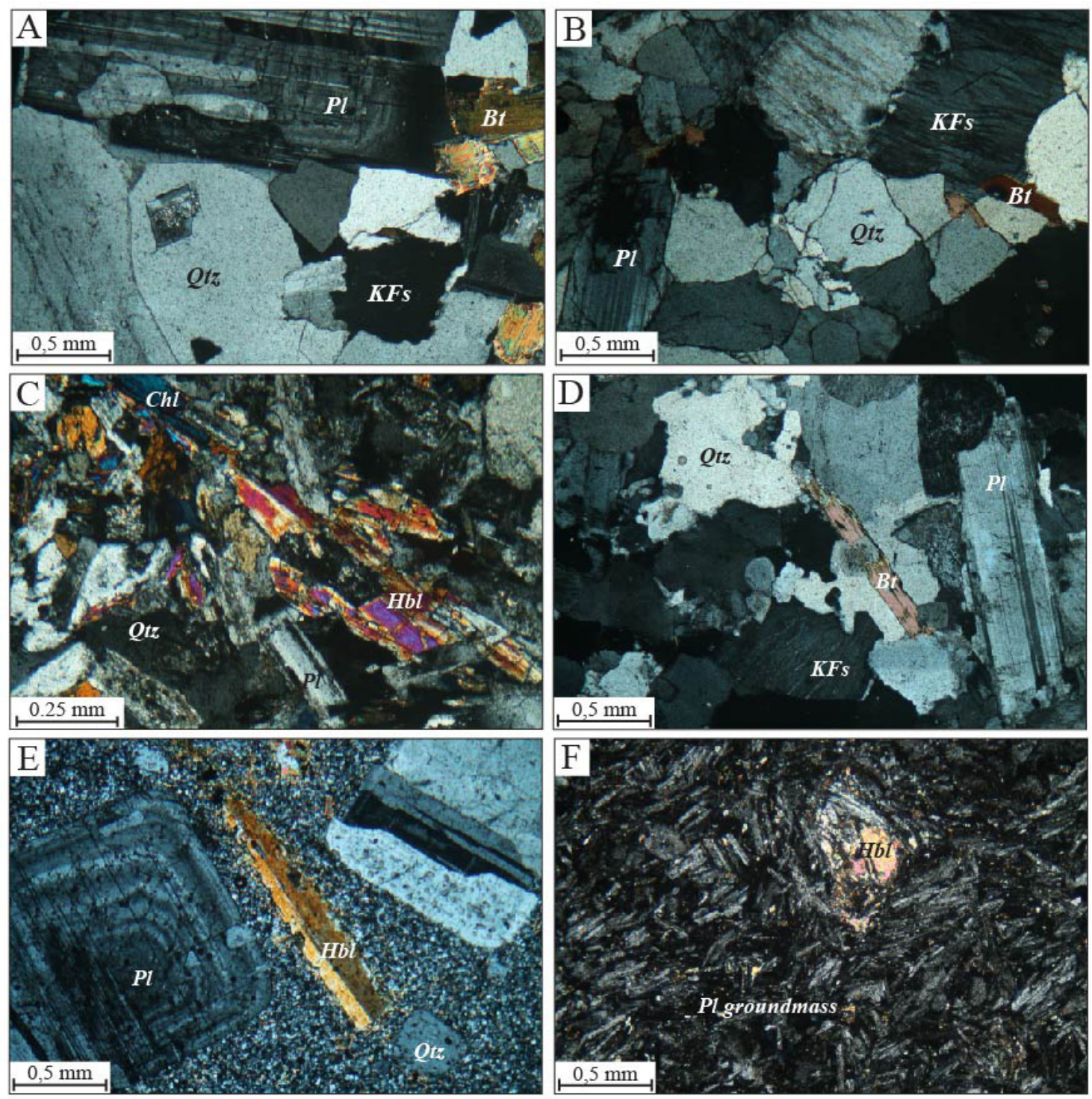

FIG. 6. Photomicrographs of dominant lithological types from Chaihuín Pluton: biotite-bearing porphyritic microgranodiorite (A) and biotite granite (B); porphyritic texture was difficult to show at this microscopic scale due to the big size of phenocrysts. Microdioritic enclave included in Chaihuín Pluton (C) (outcrop photograph in figure 5A). The others last photos correspond to samples of dikes associated to the Chaihuín intrusive: (D) aplitic dike, (E) dacitic dike, and (F) andesitic dike (outcrop photograph in Fig. 5B). Cross-polarized light view. Magnification 40x. Bt: biotite, Chl: chlorite. Hbl: hornblende, KFs: potassium feldspar, Pl: plagioclase, Qtz: quartz.

Quartz-bearing andesitic porphyry has only been observed in the Oncol Porphyry; seriated phenocrysts (up to $2 \mathrm{~mm}$ ) are dispersed in a fine-grained hypidiomorphic granular groundmass $(0.1 \mathrm{~mm})$. The main minerals are altered plagioclase $(\sim 70 \%)$, quartz ( 10\%), amphibole ( 18\%) with relicts of pyroxene ( $\sim 2 \%)$ and accessory fine opaque minerals and epidote. Secondary quartz is also found in the groundmass, with grains of up to $0.7 \mathrm{~mm}$. The Oncol Porphyry contains biotite-rich xenoliths.

Numerous aplitic, dacitic and andesitic dikes cut both the intrusions and the metamorphic basement. Aplitic dikes (Fig. 6D) have fine-grained allotriomorphic and hypidiomorphic granular texture, with a porphyritic tendency. They are composed of quartz (30-25\%), orthoclase (30\%), plagioclase 
$\left(\mathrm{An}_{28}, 5-10 \%\right)$ and biotite (15-30\%). The dacitic dikes (Fig. 6E) present a fine equigranular texture, as well as a seriated porphyritic aspect. They are composed of plagioclase $\left(\mathrm{An}_{44-32}, \sim 42-63 \%\right)$, quartz (25\%), alkali feldspar (0-15\%), amphibole (0-10\%) and biotite (4-12\%). Andesitic dikes (Ch-B5; Fig. 6F and 5B) usually have a porphyritic texture, with plagioclase ( 18\%) and amphibole (5\%) phenocrysts, in a fine-grained pilotaxitic groundmass. Plagioclase phenocrysts are replaced by sericite, calcite and clay minerals. In the surroundings of Chaihuín locality, an andesitic dike has been observed cutting an aplitic one, indicating that mafic dikes can be late in the intrusive sequence. In all dikes, minor opaque minerals, titanite and epidote are observed; apatite is restricted to more felsic dikes.

The Upper Cretaceous intrusions studied in Andean Cordillera (Gualletué Plutonic Group) are hornblende quartzdiorite, biotite tonalite and biotitehornblende granodiorite (close to tonalite). All these rocks have hipidiomorphic granular texture and are medium-grained (1-2.5 mm). The hornblende quartzdiorite is composed of plagioclase (67\%), hornblende (22\%), quartz (6\%) and opaque minerals (5\%); the biotite tonalite has plagioclase (55\%), quartz (25\%), biotite (12\%), hornblende (5\%) and opaque minerals (3\%); the biotite-hornblende granodiorite is composed of plagioclase (43\%), quartz (31\%), biotite (11\%), orthoclase (8\%), hornblende (5\%), and opaque minerals (2\%).

\section{Geochemistry}

A total of twenty two samples representative of the five studied intrusive complexes were analyzed for their major and trace elements compositions (Tables 2, 3 , 4). In addition, a total of eigth samples were also analyzed for their $\mathrm{Sr}, \mathrm{Nd}$ and $\mathrm{Pb}$ isotopic compositions (Table 5). Three samples from the Gualletué Plutonic Group were included as representatives of the Upper Cretaceous magmatic arc, contemporary with the forearc magmatism in the Coastal Cordillera.

\subsection{Analytical methods}

Geochemical analyses were conducted at the Geochemistry Laboratory of the Chilean Geology and Mining National Service (Sernageomin), by means of X-ray fluorescence spectrometry for major elements and by ICP-AES and ICP-MS for trace and rare earths elements. Isotopic analyses were conducted at the "Laboratoire de Géochimie isotopique" (ULB, Bruxelles, Belgium), with the TIMS method (Thermo-Ionization Mass Spectrometer) for $\mathrm{Sr}$ and Nd isotopes, and MC-ICP-MS (Inductively Coupled Plasma Mass Spectrometer) for Pb isotopes (see Ashwal et al., 2002 for detailed analytical methods).

\subsection{Major elements}

The Upper Cretaceous felsic plutons and stocks of the Coastal Range have typical calc-alkaline signature in the AFM diagram (Fig. 7A); they have metaluminous to peraluminous affinity (Fig. 7B), with a slightly more peraluminous composition than intrusives of the Gualletué Plutonic Group. As the Chaihuín Pluton displays a wide compositional spectrum (from diorite to granite) and has been the most largely analyzed, the Harker diagrams (Fig. 8) will be focused on this pluton and its pattern will be compared to those of the others intrusions.

Rocks from the Chaihuín Pluton show linearly decreasing $\mathrm{TiO}_{2}, \mathrm{Fe}_{2} \mathrm{O}_{3}, \mathrm{CaO}, \mathrm{MgO}, \mathrm{MnO}$ and $\mathrm{P}_{2} \mathrm{O}_{5}$ contents with increasing $\mathrm{SiO}_{2}$ values $\left(0.82<\mathrm{R}^{2}<0.94\right)$. The $\mathrm{Al}_{2} \mathrm{O}_{3}$ contents also decrease with increasing $\mathrm{SiO}_{2}$ but the trend is more scattered, especially in the less differentiated rocks. This dispersion is probably related to the variable proportions of plagioclase phenocrysts. The $\mathrm{K}_{2} \mathrm{O}$ contents increase linearly with $\mathrm{SiO}_{2}$ content, whereas $\mathrm{Na}_{2} \mathrm{O}$ is scattered.

The other stocks present major elements variations similar to those of the Chaihuín Pluton, with the following exceptions: Oncol Porphyry (sample GdO-1) is significantly enriched in $\mathrm{Al}_{2} \mathrm{O}_{3}$ and $\mathrm{K}_{2} \mathrm{O}$ for the same $\mathrm{SiO}_{2}$ content but has lower values of $\mathrm{MgO}, \mathrm{MnO}, \mathrm{Na}_{2} \mathrm{O}$ and $\mathrm{P}_{2} \mathrm{O}_{5}$. A sample from Los Boldos Granitoids (sample DiLb-1) has a higher $\mathrm{Na}_{2} \mathrm{O}$ content and a lower $\mathrm{K}_{2} \mathrm{O}$ concentration. The 3 samples from Gualletué Plutonic Group are quite similar to the Chaihuín Pluton variation trend.

\subsection{Trace elements}

Trace element contents are reported versus $\mathrm{SiO}_{2}$ content in figure 9. Chaihuín Pluton rocks display in general smooth and continuous trends. Incompatible elements show contrasting behaviors: Rb content is continuously increasing; $\mathrm{Pb}$ also increase but with some scatter while $\mathrm{Zr}$ content remains roughly constant from 58 to $68 \mathrm{wt} \% \mathrm{SiO}_{2}$, then decreases significantly. 
TABLE 2. MAJOR ELEMENT CONTENTS (wt.\%) OF THE STUDIED SAMPLES, GROUPED IN CHAIHUÍN (CHA), ONCOL (ONC), LAUREL (LAU), LOS BOLDOS (BOL), LONCOCHE (LON) AND GUALLETUÉ (GUA) INTRUSIVES.

\begin{tabular}{|c|c|c|c|c|c|c|c|c|c|c|c|c|c|}
\hline Unit & Sample & $\mathrm{SiO}_{2}$ & $\mathrm{Al}_{2} \mathrm{O}_{3}$ & $\mathrm{Fe}_{2} \mathrm{O}_{3}$ & MgO & MnO & $\mathrm{CaO}$ & $\mathrm{Na}_{2} \mathrm{O}$ & $\mathrm{K}_{2} \mathrm{O}$ & $\mathrm{TiO}_{2}$ & $\mathbf{P}_{2} \mathbf{O}_{5}$ & PPC & $\Sigma$ \\
\hline \multirow[t]{14}{*}{ CHA } & Ch-I2 & 67.50 & 14.65 & 3.69 & 3.00 & 0.06 & 3.49 & 3.58 & 2.42 & 0.54 & 0.16 & 0.49 & 99.56 \\
\hline & Ch-I6 & 66.11 & 14.73 & 4.37 & 3.42 & 0.09 & 3.49 & 3.31 & 2.13 & 0.50 & 0.18 & 1.39 & 99.71 \\
\hline & Ch-A2 & 62.05 & 15.05 & 5.94 & 4.60 & 0.10 & 3.58 & 3.78 & 2.06 & 0.80 & 0.24 & 1.42 & 99.63 \\
\hline & Ch-B5 & 58.03 & 15.60 & 5.80 & 6.18 & 0.10 & 4.96 & 4.03 & 1.30 & 0.62 & 0.28 & 2.83 & 99.75 \\
\hline & Gdch-1 & 74.78 & 14.19 & 1.01 & 0.31 & 0.02 & 1.27 & 3.54 & 4.06 & 0.23 & 0.02 & 0.27 & 99.69 \\
\hline & Gdch-2 & 73.05 & 14.42 & 1.58 & 0.65 & 0.04 & 2.04 & 3.90 & 3.43 & 0.26 & 0.03 & 0.18 & 99.58 \\
\hline & Gdch-3 & 76.28 & 12.92 & 0.79 & 0.19 & 0.02 & 0.63 & 3.76 & 4.68 & 0.12 & 0.01 & 0.24 & 99.63 \\
\hline & Gdch-4 & 74.89 & 14.21 & 0.87 & 0.21 & 0.02 & 0.76 & 3.70 & 4.51 & 0.12 & 0.02 & 0.27 & 99.57 \\
\hline & Gdch-5 & 70.17 & 15.86 & 2.27 & 1.11 & 0.04 & 2.78 & 4.13 & 2.37 & 0.39 & 0.05 & 0.37 & 99.53 \\
\hline & Gdch-7 & 63.94 & 16.44 & 3.82 & 2.17 & 0.07 & 3.80 & 4.47 & 2.02 & 0.60 & 0.10 & 2.42 & 99.85 \\
\hline & Gdch-8 & 68.69 & 16.45 & 2.36 & 1.21 & 0.04 & 3.11 & 3.98 & 2.83 & 0.40 & 0.05 & 0.48 & 99.60 \\
\hline & Gdch-9 & 70.93 & 15.39 & 1.96 & 0.92 & 0.04 & 2.34 & 3.84 & 3.32 & 0.35 & 0.04 & 0.42 & 99.54 \\
\hline & Gdch-10 & 67.26 & 15.91 & 2.83 & 1.29 & 0.05 & 3.21 & 4.21 & 2.41 & 0.52 & 0.07 & 1.84 & 99.60 \\
\hline & Gdch-11 & 69.27 & 16.02 & 2.51 & 0.99 & 0.04 & 3.17 & 3.92 & 2.71 & 0.47 & 0.06 & 0.52 & 99.66 \\
\hline ONC & GdO-1 & 59.76 & 18.28 & 6.34 & 2.62 & 0.04 & 5.18 & 1.68 & 2.79 & 0.48 & 0.07 & 2.45 & 99.69 \\
\hline LAU & DL-1 & 64.56 & 16.86 & 3.10 & 1.91 & 0.06 & 3.84 & 4.06 & 2.26 & 0.46 & 0.07 & 2.53 & 99.71 \\
\hline \multirow[t]{4}{*}{ BOL } & GdLb-1 & 68.01 & 16.25 & 2.47 & 1.49 & 0.04 & 3.08 & 4.62 & 2.01 & 0.40 & 0.07 & 1.19 & 99.63 \\
\hline & GdLb-2 & 70.54 & 15.99 & 1.68 & 0.64 & 0.04 & 1.78 & 4.17 & 3.25 & 0.27 & 0.04 & 1.23 & 99.64 \\
\hline & DiLb-1 & 69.40 & 16.32 & 1.92 & 1.43 & 0.03 & 2.35 & 5.51 & 1.13 & 0.28 & 0.05 & 1.14 & 99.55 \\
\hline & XI-1347 & 68.63 & 16.76 & 2.32 & 1.07 & 0.04 & 2.28 & 4.72 & 1.91 & 0.36 & 0.05 & 1.50 & 99.63 \\
\hline \multirow[t]{2}{*}{ LON } & XI-1245 & 70.84 & 16.15 & 1.84 & 0.57 & 0.02 & 1.38 & 3.99 & 2.44 & 0.32 & 0.03 & 2.15 & 99.72 \\
\hline & XI-1255 & 67.32 & 18.20 & 2.07 & 0.68 & 0.03 & 1.68 & 3.64 & 2.21 & 0.33 & 0.04 & 3.65 & 99.86 \\
\hline \multirow[t]{3}{*}{ GUA } & Ga-M5 & 64.75 & 15.11 & 4.35 & 3.59 & 0.09 & 4.83 & 3.27 & 2.34 & 0.53 & 0.16 & 0.54 & 99.56 \\
\hline & Ga-M6 & 66.17 & 15.29 & 3.85 & 2.95 & 0.10 & 4.57 & 3.53 & 2.10 & 0.45 & 0.17 & 0.43 & 99.61 \\
\hline & Ga-M7 & 60.28 & 15.85 & 6.31 & 4.52 & 0.12 & 5.65 & 3.32 & 2.29 & 0.81 & 0.22 & 0.42 & 99.80 \\
\hline
\end{tabular}

The transition elements (Ni, Cr, V) which are generally compatible, decrease strongly and rapidly with increasing $\mathrm{SiO}_{2}$; the mafic enclave Ch-A2 has the highest content. Although Co is generally compatible in magmatic differentiation, in Chaihuín Pluton its contents augment with increasing $\mathrm{SiO}_{2}$ content which is puzzling. Sr, which is compatible when plagioclase is fractionating, also decreases linearly. Ba trend is more scattered. Y and La increase but at Chaihuín Pluton two samples have Y contents over $40 \mathrm{ppm}$.

The samples from the Laurel and Loncoche porphyries grossly follow the Chaihuín trends, although those of Los Boldos Granitoids have lower contents of La. The only sample analyzed for Oncol Porphyry 
TABLE 3. TRACE ELEMENT CONTENTS OF THE STUDIED SAMPLES, GROUPED IN THE INTRUSIVES OF CHAIHUÍN (CHA), ONCOL (ONC), LAUREL (LAU), LOS BOLDOS (BOL), LONCOCHE (LON) AND GUALLETUÉ (GUA) INTRUSIVES. VALUES ARE EXPRESSED IN PPM.

\begin{tabular}{|c|c|c|c|c|c|c|c|c|c|c|c|c|c|c|}
\hline Unit & Sample & $\mathbf{R b}$ & $\mathrm{Sr}$ & Ba & $\mathbf{P b}$ & $\mathbf{Y}$ & $\mathrm{Zr}$ & $\mathbf{N b}$ & Co & $\mathrm{Ni}$ & $\mathbf{C u}$ & $\mathrm{Zn}$ & $\mathrm{Cr}$ & $\mathbf{V}$ \\
\hline \multirow[t]{14}{*}{ CHA } & Ch-I2 & 43 & 248 & 279 & 5.7 & 43.5 & 158 & $<5$ & 8 & 26 & $<5$ & 82 & 45 & 75 \\
\hline & Ch-I6 & 55 & 239 & 268 & 14.3 & 22.5 & 168 & $<5$ & 11 & 29 & $<5$ & 67 & 54 & 65 \\
\hline & Ch-A2 & 63 & 209 & 362 & 6.0 & 40.5 & 161 & $<5$ & 17 & 46 & 62 & 107 & 84 & 213 \\
\hline & Ch-B5 & 22 & 666 & 304 & 11.7 & 9.5 & 173 & $<5$ & 17 & 24 & 14 & 102 & 43 & 110 \\
\hline & Gdch-1 & 147 & 88 & 364 & 15.0 & 23.8 & 104 & $<5$ & 194 & $<2$ & 16 & 16 & 19 & 13 \\
\hline & Gdch-2 & 136 & 134 & 310 & 16.0 & 17.8 & 86 & $<5$ & 145 & 2 & 11 & 30 & 20 & 20 \\
\hline & Gdch-3 & 185 & 28 & 246 & 22.0 & 25.0 & 75 & 5 & 215 & $<2$ & 8 & 14 & 7 & 5 \\
\hline & Gdch-4 & 178 & 39 & 356 & 20.0 & 21.2 & 68 & $<5$ & 162 & $<2$ & 6 & 14 & 10 & 5 \\
\hline & Gdch-5 & 122 & 205 & 460 & 11.0 & 16.0 & 124 & 5 & 127 & 6 & 10 & 36 & 12 & 42 \\
\hline & Gdch-7 & 101 & 332 & 302 & $<4$ & 14.4 & 155 & 5 & 60 & 30 & 41 & 57 & 58 & 71 \\
\hline & Gdch-8 & 105 & 179 & 306 & 12.0 & 17.7 & 109 & $<5$ & 90 & 6 & 123 & 41 & 28 & 36 \\
\hline & Gdch-9 & 124 & 135 & 336 & 12.0 & 19.1 & 103 & 5 & 96 & 4 & 14 & 25 & 21 & 28 \\
\hline & Gdch-10 & 78 & 221 & 347 & 6.0 & 15.8 & 141 & $<5$ & 58 & 8 & 7 & 47 & 18 & 40 \\
\hline & Gdch-11 & 121 & 194 & 433 & 13.0 & 15.1 & 114 & $<5$ & $<2$ & 3 & 157 & 36 & 8 & 40 \\
\hline ONC & GdO-1 & 148 & 184 & 342 & $<4$ & 15.9 & 104 & 5 & 52 & 8 & 860 & 57 & 27 & 37 \\
\hline LAU & DL-1 & 89 & 269 & 466 & 12.0 & 15.7 & 120 & 6 & 30 & 11 & 24 & 48 & 28 & 41 \\
\hline \multirow[t]{4}{*}{ BOL } & GdLb-1 & 50 & 348 & 491 & 12.0 & 6.9 & 125 & $<5$ & 77 & 12 & 14 & 63 & 35 & 41 \\
\hline & GdLb-2 & 118 & 233 & 384 & 24.0 & 11.9 & 68 & $<5$ & 93 & $<2$ & 45 & 45 & 9 & 25 \\
\hline & DiLb-1 & 32 & 327 & 343 & 22.0 & 6.1 & 92 & $<5$ & 91 & 37 & 23 & 45 & 39 & 31 \\
\hline & XI-1347 & 59 & 362 & 262 & 9.0 & 7.1 & 97 & $<5$ & $<2$ & 6 & 32 & 56 & 18 & 38 \\
\hline \multirow[t]{2}{*}{ LON } & XI-1245 & 78 & 238 & 323 & 16.0 & 8.1 & 93 & $<5$ & $<2$ & $<2$ & 7 & 46 & 12 & 22 \\
\hline & XI-1255 & 68 & 288 & 326 & 31.0 & 8.2 & 97 & $<5$ & $<2$ & $<2$ & 57 & 50 & 14 & 28 \\
\hline \multirow[t]{3}{*}{ GUA } & Ga-M5 & 28 & 505 & 274 & 19.1 & 8.3 & 161 & $<5$ & 11 & 25 & 22 & 70 & 46 & 64 \\
\hline & Ga-M6 & 26 & 593 & 250 & 10.9 & 8.4 & 151 & $<5$ & 10 & 17 & 11 & 78 & 47 & 27 \\
\hline & Ga-M7 & 26 & 503 & 350 & 11.0 & 8.5 & 179 & $<5$ & 19 & 35 & 58 & 91 & 63 & 181 \\
\hline
\end{tabular}

(GdO-1) is distinctly enriched in Rb (148 ppm) but depleted in Sr (184 ppm) when compared to Chaihuín rocks. Intrusives from the Cretaceous arc generally follow the Chaihuín trends.

\subsection{Rare earths elements (REE)}

The chondrite-normalized REE patterns of the intrusives are shown in figure 10. All the rocks of the Chaihuín Pluton display sub-parallel patterns (Fig. 10A), with LREE enrichments (La/Yb: 9-14), rather flat HREE and negative Eu anomaly $\left(\mathrm{Eu} / \mathrm{Eu}^{*}=0.05-0.30\right)$, except for the andesitic dike (sample Ch-B5). This anomaly is significantly more pronounced in the most differentiated rocks. REE content slightly increases with increasing $\mathrm{SiO}_{2}$. The mafic enclave sample (Ch-A2) exhibits more enriched pattern, especially in MREE. Oncol and Laurel porphyries show similar patterns (Fig. 10B) which fall in the range of the Chaihuín samples. Granitoids from Los Boldos and dacitic 
TABLE 4. REE CONTENTS OF THE STUDIED SAMPLES, GROUPED IN CHAIHUÍN (CHA), ONCOL (ONC), LAUREL (LAU), LOS BOLDOS (BOL), LONCOCHE (LON) AND GUALLETUÉ (GUA) INTRUSIVES. VALUES ARE EXPRESSED IN PPM.

\begin{tabular}{|c|c|c|c|c|c|c|c|c|c|c|c|c|c|c|c|c|c|c|}
\hline Unit & Sample & La & Ce & Pr & Nd & Sm & Eu & Gd & $\mathbf{T b}$ & Dy & Ho & Er & $\mathbf{T m}$ & $\mathbf{Y b}$ & Lu & $\sum$ & $\mathbf{L a} / \mathbf{Y b}$ & $\mathbf{E u} / \mathbf{E u}^{*}$ \\
\hline \multirow[t]{14}{*}{ CHA } & Ch-I2 & 23.2 & 47.1 & 5.65 & 19.2 & 4.58 & .01 & 4 & 0.70 & 3.95 & 0.85 & 2.45 & 0.34 & 2.26 & 0.36 & 116.05 & 10.26 & 0.67 \\
\hline & Ch-I6 & 20.1 & 6 & 493 & 17.7 & 4.46 & 1.22 & 4.38 & 0.72 & 4.08 & 0.92 & 2.60 & .35 & 2.29 & .35 & 104.66 & 8.74 & 0.83 \\
\hline & Ch-A2 & 24.7 & 53.0 & 6.46 & 24.2 & 5.56 & 1.31 & 5.64 & 0.91 & 5.07 & 1.14 & 3.12 & 47 & 2.83 & 0.46 & 134.89 & 8.72 & 0.71 \\
\hline & Ch-B5 & 18.0 & 37.4 & 4.59 & 17.4 & 3.76 & 1.06 & 3.31 & 0.51 & 2.59 & 0.55 & 1.56 & 0.24 & 1.37 & 0.22 & 92.60 & 13.19 & 0.90 \\
\hline & Gdch-1 & 22.2 & 45.4 & 4.92 & 18.9 & 3.75 & 0.46 & 3.67 & 0.62 & 3.93 & 0.86 & 2.41 & 36 & 2.37 & 0.36 & 110.25 & 9.38 & 0.38 \\
\hline & Gdch-2 & 21.7 & 44.3 & 4.62 & 16.9 & 3.17 & 0.50 & 2.90 & 0.47 & 2.91 & 0.63 & 1.84 & 0.29 & 2.03 & 0.31 & 102.57 & 10.66 & 0.50 \\
\hline & Gdch-3 & 25.0 & 51.9 & 5.48 & 20.2 & 3.87 & 0.17 & 3.48 & 0.59 & 3.77 & 0.83 & 2.49 & 39 & 2.76 & 0.42 & 121.36 & 9.06 & 0.14 \\
\hline & Gdch-4 & 27.3 & 56.2 & 5.79 & 21.2 & 3.90 & 0.24 & 3.52 & 0.58 & 3.69 & 0.80 & 2.28 & 0.35 & 2.36 & 0.36 & 128.55 & 11.57 & 0.19 \\
\hline & Gdch-5 & 22.9 & 45.9 & 4.81 & 18.2 & 3.33 & 0.67 & 2.94 & 0.45 & 2.76 & 0.58 & 1.64 & 0.24 & 1.66 & 0.26 & 106.42 & 13.79 & 0.64 \\
\hline & Gdch-7 & 17.2 & 35.8 & 4.01 & 16.4 & 3.30 & 0.89 & 2.94 & 0.44 & 2.63 & 0.54 & 1.43 & 0.20 & 1.30 & 0.19 & 87.24 & 13.21 & 0.86 \\
\hline & Gdch-8 & 20.9 & 43.6 & 4.66 & 17.9 & 3.50 & 0.71 & 3.17 & 0.50 & 3.10 & 0.66 & 1.82 & 0.27 & 1.85 & 0.28 & 102.93 & 11.31 & 0.64 \\
\hline & Gdch-9 & 22.0 & 45.2 & 4.83 & 18.3 & 3.50 & 0.55 & 3.15 & 0.52 & 3.24 & 0.70 & 1.99 & 0.30 & 2.07 & 0.31 & 106.70 & 10.63 & 0.49 \\
\hline & Gdch-10 & 17.4 & 33.6 & 3.69 & 15.0 & 3.13 & 0.85 & 2.98 & 0.48 & 2.91 & 0.60 & 1.65 & 0.23 & 1.54 & 0.23 & 84.35 & 11.28 & 0.83 \\
\hline & Gdch-11 & 15.0 & 30.7 & 3.44 & 13.8 & 2.99 & 0.77 & 2.84 & 0.47 & 2.85 & 0.60 & 1.65 & 0 & 1.54 & 0.23 & 77.16 & 9.74 & 0.79 \\
\hline ONC & GdO-1 & 16.0 & 33.7 & 3.78 & 15.2 & 3.09 & 0.75 & 2.87 & 0.47 & 2.84 & 0.60 & 1.62 & 0.23 & 1.57 & 0.24 & 82.94 & 10.20 & 0.75 \\
\hline LAU & DL-1 & 20.1 & 39.8 & 4.29 & 16.8 & 3.27 & 0.84 & 2.97 & 0.46 & 2.78 & 0.57 & 1.56 & 0.23 & 1.50 & 0.23 & 95.40 & 13.45 & 0.80 \\
\hline \multirow[t]{4}{*}{ BOL } & GdLb-1 & 13.4 & 28.8 & 3.37 & 13.8 & 2.69 & 0.78 & 2.05 & 0.27 & 1.37 & 0.26 & 0.64 & 0.09 & 0.54 & 0.08 & 68.13 & 25.00 & 0.98 \\
\hline & XI-1347 & 9.91 & 20.3 & 2.53 & 10.3 & 2.19 & 0.66 & 1.79 & 0.26 & 1.47 & 0.29 & 0.79 & 0. & 0.80 & 0.11 & 51.45 & 12.45 & 0.98 \\
\hline & DiLb-1 & 7.67 & 16.6 & 1.97 & 7.9 & 1.77 & 0.54 & 1.57 & 0.22 & 1.20 & 0.23 & 0.58 & 0.08 & 0.53 & 0.08 & 40.95 & 14.42 & 0.96 \\
\hline & GdLb-2 & 10.8 & 22.4 & 2.69 & 11.0 & 2.62 & 0.64 & 2.36 & 0.38 & 2.28 & 0.48 & 1.26 & 0.18 & 1.18 & 0.17 & 58.36 & 9.15 & 0.76 \\
\hline \multirow[t]{2}{*}{ LON } & XI-1255 & 13.9 & 28.0 & 3.29 & 13.0 & 2.48 & 0.80 & 1.83 & 0.24 & 1.27 & 0.24 & 0.64 & 0.09 & 0.62 & 0.09 & 66.48 & 22.40 & 1.09 \\
\hline & XI-1245 & 16.3 & 32.9 & 3.88 & 15.5 & 2.91 & 0.79 & 2.29 & 0.30 & 1.60 & 0.30 & 0.80 & 0.11 & 0.68 & 0.10 & 78.50 & 23.93 & 0.90 \\
\hline \multirow[t]{3}{*}{ GUA } & Ga-M7 & 19.4 & 44.3 & 5.75 & 22.0 & 5.31 & 1.32 & 4.88 & 0.80 & 4.59 & 0.99 & 2.93 & 0.43 & 2.70 & 0.44 & 115.80 & 7.18 & 0.78 \\
\hline & Ga-M5 & 16.3 & 37.2 & 4.71 & 18.3 & 4.42 & 1.03 & 4.00 & 0.66 & 3.71 & 0.82 & 2.35 & 0.36 & 2.30 & 0.35 & 96.58 & 7.09 & 0.73 \\
\hline & Ga-M6 & 17.7 & 36.6 & 4.63 & 17.3 & 3.61 & 1.02 & 3.49 & 0.54 & 2.87 & 0.64 & 1.92 & 0.31 & 1.86 & 0.32 & 92.83 & 9.54 & 0.87 \\
\hline
\end{tabular}

porphyries from Loncoche (Fig. 10C) are characterized by a notorious HREE depletion and thus by higher $\mathrm{La} /$ $\mathrm{Yb}$ ratios (up to 25) and by the absence of significant Eu anomalies. Sample GdLb-2 (Los Boldos Granitoid) shows comparatively HREE enrichment and a slight negative Eu anomaly.

The granitoids from the Gualletué Plutonic Group present moderately inclined and sub-parallel patterns
( $\mathrm{La} / \mathrm{Yb}=7$ to 10 ), with flat slope for HREE, similar to the Chaihuín Plutons.

\subsection{Isotopic geochemistry}

The Sr, $\mathrm{Nd}$ and $\mathrm{Pb}$ isotopic compositions (Table 5) have been measured for 10 samples: 8 from the forearc intrusions and 2 from the Gualletué Plutonic Group. 
TABLE 5. Sr, Nd AND Pb ISOTOPIC COMPOSITION OF FOREARC (CHAIHUÍN, LAUREL, ONCOL, LOS BOLDOS, LONCOCHE) AND ARC (GUALLETUÉ) INTRUSIVES.

\begin{tabular}{|c|c|c|c|c|c|c|c|c|c|c|}
\hline \multirow{2}{*}{$\begin{array}{c}\text { Unit } \\
\text { Sample }\end{array}$} & \multicolumn{4}{|c|}{ CHA } & \multirow{2}{*}{$\begin{array}{l}\text { LAU } \\
\text { DL-1 }\end{array}$} & \multirow{2}{*}{$\begin{array}{c}\text { ONC } \\
\text { GdO-1 }\end{array}$} & \multirow{2}{*}{$\begin{array}{c}\text { BOL } \\
\text { GdLb-1 }\end{array}$} & \multirow{2}{*}{$\begin{array}{c}\text { LON } \\
\text { XI-1255 }\end{array}$} & \multicolumn{2}{|c|}{ GUA } \\
\hline & Gdch-4 & Ch-I2 & Ch-B5 & Ch-A2 & & & & & Ga-M5 & Ga-M7 \\
\hline Rock & $\begin{array}{l}\text { micro- } \\
\text { granite }\end{array}$ & $\begin{array}{l}\text { microgra- } \\
\text { nodiorite }\end{array}$ & $\begin{array}{l}\text { andesitic } \\
\text { dike }\end{array}$ & $\begin{array}{c}\text { mafic } \\
\text { enclave }\end{array}$ & $\begin{array}{c}\text { dacitic } \\
\text { porphyry }\end{array}$ & $\begin{array}{l}\text { andesitic } \\
\text { porphyry }\end{array}$ & $\begin{array}{c}\text { dacitic } \\
\text { porphyry }\end{array}$ & $\begin{array}{c}\text { dacitic } \\
\text { porphyry }\end{array}$ & $\begin{array}{l}\text { grano- } \\
\text { diorite }\end{array}$ & tonalite \\
\hline Age (Ma) & $86^{(1)}$ & $92^{(1)}$ & $91^{(2)}$ & - & - & $91^{(3)}$ & $89^{(4)}$ & $87^{(4)}$ & $86^{(5)}$ & $83^{(6)}$ \\
\hline${ }^{87} \mathrm{Rb} /{ }^{86} \mathrm{Sr}$ & 13.23 & 0.5019 & 0.0956 & 0.8727 & 0.9577 & 2.33 & 0.4158 & 0.6834 & 0.1605 & 0.1496 \\
\hline${ }^{87} \mathrm{Sr} /{ }^{86} \mathrm{Sr}$ & 0.721258 & 0.706161 & 0.704850 & 0.708578 & 0.707302 & 0.710127 & 0.704624 & 0.705509 & 0.70443 & 0.704292 \\
\hline${ }^{87} \mathrm{Sr} /{ }^{86} \mathrm{Sr}(\mathrm{t})$ & 0.704152 & 0.705512 & 0.704726 & 0.70745 & 0.706118 & 0.707116 & 0.70411 & 0.704664 & 0.704236 & 0.704111 \\
\hline${ }^{147} \mathrm{Sm} /{ }^{144} \mathrm{Nd}$ & 0.1112 & 0.1442 & 0.1306 & 0.1389 & 0.1177 & 0.1229 & 0.1179 & 0.1153 & 0.146 & 0.1459 \\
\hline${ }^{143} \mathrm{Nd} /{ }^{144} \mathrm{Nd}$ & 0.512734 & 0.512711 & 0.512752 & 0.512543 & 0.512543 & 0.512433 & 0.512809 & 0.512646 & 0.512796 & 0.512822 \\
\hline${ }^{143} \mathrm{Nd} /{ }^{144} \mathrm{Nd}(\mathrm{t})$ & 0.512663 & 0.51262 & 0.512669 & 0.512455 & 0.512478 & 0.512355 & 0.512744 & 0.512582 & 0.512715 & 0.512741 \\
\hline$\varepsilon N d(t)$ & +2.94 & +2.07 & +3.04 & -1.13 & -0.94 & -3.09 & 4.24 & 1.09 & 3.62 & 4.13 \\
\hline${ }^{206} \mathrm{~Pb} /{ }^{204} \mathrm{~Pb}$ & 18.6857 & 18.698 & 18.6161 & 18.7084 & 18.7091 & 19.269 & 18.5674 & 18.5798 & 18.6336 & 18.5731 \\
\hline${ }^{207} \mathrm{~Pb} /{ }^{204} \mathrm{~Pb}$ & 15.6345 & 15.6255 & 15.6204 & 15.6234 & 15.6399 & 15.7751 & 15.6355 & 15.6221 & 15.6007 & 15.6007 \\
\hline${ }^{208} \mathrm{~Pb} /{ }^{204} \mathrm{~Pb}$ & 38.6642 & 38.6289 & 38.5726 & 38.6287 & 38.7215 & 39.5696 & 38.4959 & 38.5600 & 38.5757 & 38.4703 \\
\hline
\end{tabular}

Initial (t) Sr and Nd isotopic compositions were calculated for the emplacement ages, whose references are given in table 1.

References: 1) Duhart et al., 1997; 2) Martin et al., 1999; 3) Sernageomin, 1998; 4) Quiroz et al., 2007; 5) Suárez et al., 1986; 6) IIG/MMAJ/JICA (1978).

Initial Sr and Nd isotopic compositions, recalculated for an average age of $90 \mathrm{Ma}$, have been plotted in the classical Nd-Sr isotopic diagram (Fig.11), including the data of metamorphic basement rocks (Lucassen et al. (2004).

Samples from the Chaihuín Pluton show a rather restricted ranges of initial isotopic compositions $\left({ }^{87} \mathrm{Sr} /{ }^{86} \mathrm{Sr}\right)$ ratios vary from 0.70415 to 0.70551 and $\varepsilon \mathrm{Nd}(\mathrm{t})$ values from +2.07 to +3.04 . The mafic enclave Ch-A2 has a distinct signature, 0.70745 and -1.13 respectively. The isotopic compositions of the Los Boldos granitoid and Loncoche dacitic porphyry $\left({ }^{87} \mathrm{Sr} /{ }^{86} \mathrm{Sr}\right)_{\mathrm{t}}=0.70411$ and $0.70466 ; \varepsilon \mathrm{Nd}(\mathrm{t})=+4.24$ and +1.09 respectively) fall in the Chaihuín domain. By contrast, the andesitic porphyry from Oncol and the Laurel dacitic porphyry are grossly similar (0.70711 and 0.70612 ; -3.09 and -0.94 respectively) and more evolved than the Chaihuín rocks. The two samples from the Gualletué Plutonic Group have isotopic compositions $(0.70424 ;+4.13$ and +3.62$)$ that are quite similar to those in the Chaihuín Pluton.
As $\mathrm{U}$ and Th concentrations have not been measured, it is not possible to recalculate the initial $\mathrm{Pb}$ isotopic compositions but for rather young rocks ( $90 \mathrm{Ma})$, the measured $\mathrm{Pb}$ compositions are presumably still close to the initial compositions. The 4 Chaihuín samples display narrow range of values, with ${ }^{206} \mathrm{~Pb} /{ }^{204} \mathrm{~Pb}$ : 18.616 to $18.708 ;{ }^{207} \mathrm{~Pb} /{ }^{204} \mathrm{~Pb}$ : 15.620 to $15.635 ;{ }^{208} \mathrm{~Pb} / 2{ }^{204} \mathrm{~Pb}$ : 38.573 to 38.662. The isotopic composition of samples from the Laurel, Loncoche and Los Boldos intrusives as well as those of the Gualletué plutonic rocks are similar to those of the Chaihuín Pluton.

\section{Discussion}

The studied Upper Cretaceous intrusive rocks of the present-day forearc Coastal Range near Valdivia (Table 6) correspond to epizonal plutons with subtle geochemical differences compared to the typical arc granitoids located in the Andean Cordillera (Gualletué Plutonic Group). Coastal intrusive rocks show: a) slightly more peraluminous character with 
A
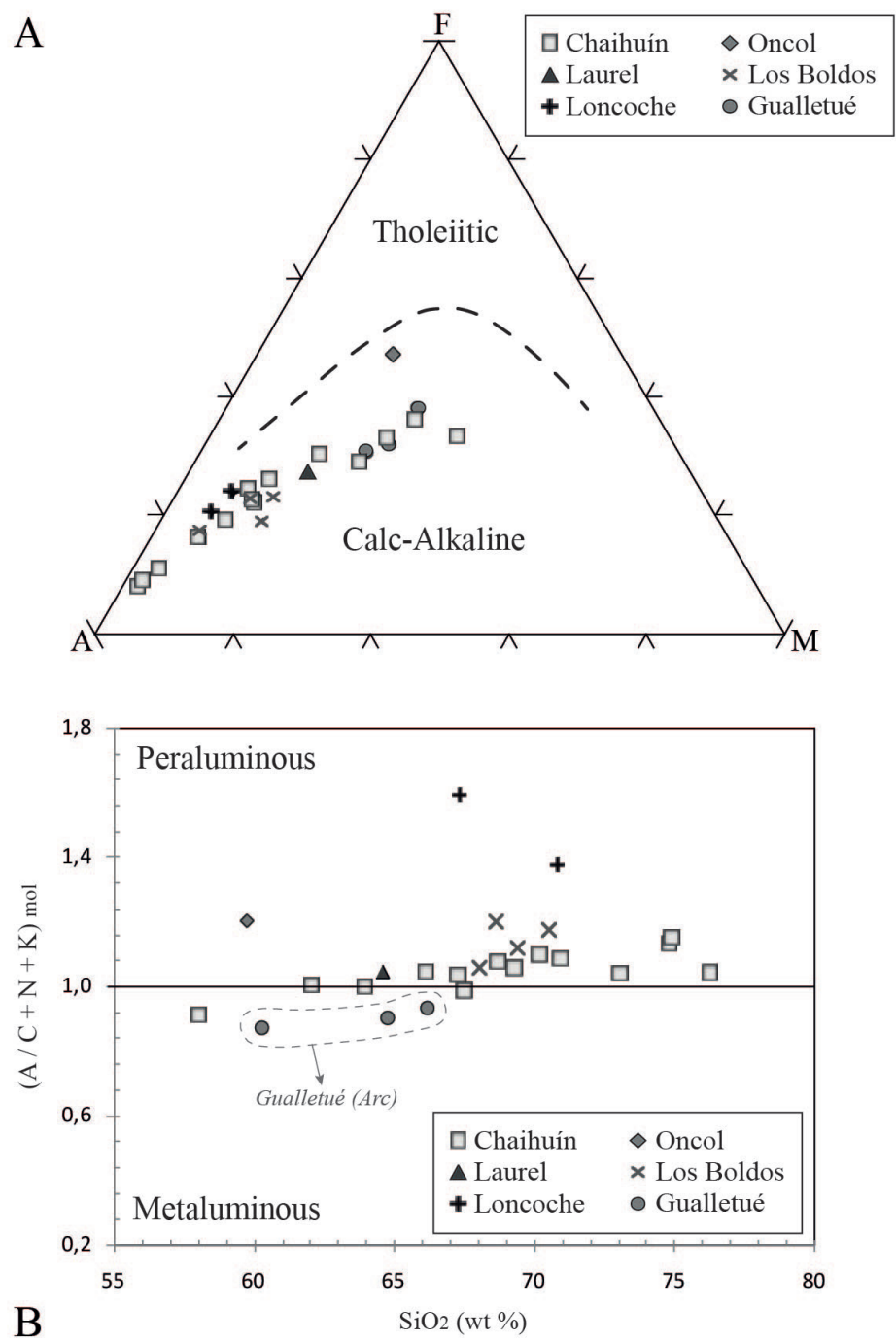

FIG. 7. Discriminant diagrams for the studied intrusives: A. AFM diagram for the forearc bodies $\left(\mathrm{A}=\mathrm{Na}_{2} \mathrm{O}+\mathrm{K}_{2} \mathrm{O} ; \mathrm{F}=\mathrm{FeO}+\mathrm{Fe} \mathrm{O}_{3}\right.$; $\mathrm{M}=\mathrm{MgO}$ ), that differentiates between tholeitic and calc-alkaline rocks (Irvine and Baragar, 1971). B. ASI diagram (Aluminum Saturation Index $)$ determined for $\mathrm{A} / \mathrm{C}+\mathrm{N}+\mathrm{K}\left(\mathrm{Al}_{2} \mathrm{O}_{3} / \mathrm{CaO}+\mathrm{Na}_{2} \mathrm{O}+\mathrm{K}_{2} \mathrm{O}\right)$ molar versus $\mathrm{SiO}_{2}$, which divides peraluminous and metaluminous fields (Shand, 1927); samples enclosed by dotted line belong to Gualletué Group (arc plutons).

$(\mathrm{A} / \mathrm{C}+\mathrm{N}+\mathrm{K})>1$ (Fig. 7B); b) higher contents in Large Ion Lithophile elements (such as $\mathrm{Rb}$ and $\mathrm{Ba}$ ) but lower contents of $\mathrm{Sr}$ and $\mathrm{P}$ than the rocks from the Upper Cretaceous magmatic arc (Fig. 12); c) their REE patterns are steeper $(\mathrm{La} / \mathrm{Yb}=9-25)$ than those of Gualletué Plutonic Group (La/Yb=7-10) (Fig. 10). On the other hand, these intrusives are quite similar in petrography, $\mathrm{SiO}_{2}$ range and $\mathrm{Sr}$ and $\mathrm{Nd}$ isotopes to others forearc granitoids around the world (Table 7), although the Kodiak batholith (Farris, 2010) is strongly peraluminous due to the occurrence of kyanite and andalusite xenocrysts.

In the following sections the petrogenesis of these rocks will be addressed with the aim to discuss whether these rocks formed during the subduction of an active oceanic spreading ridge. 

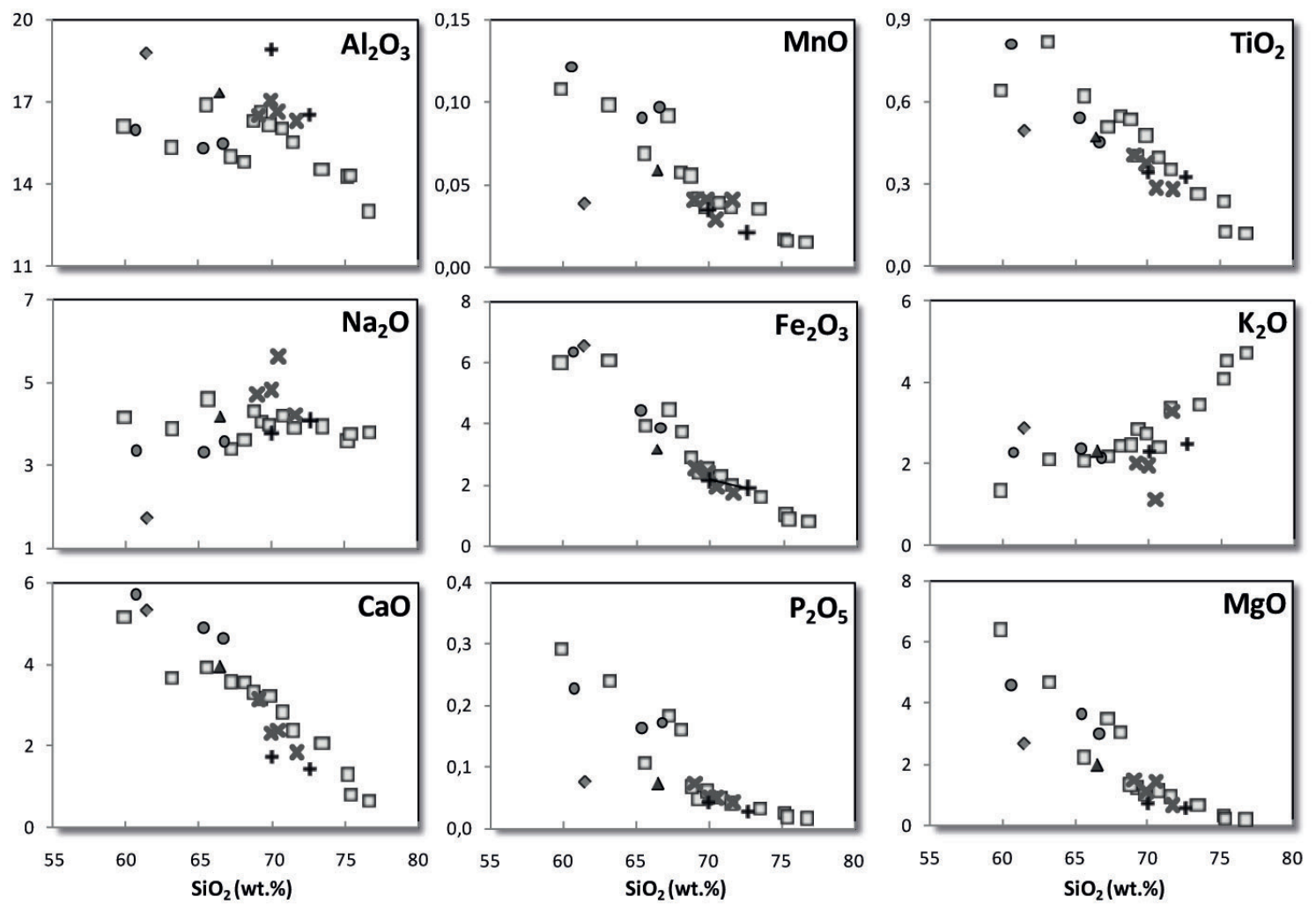

$$
\begin{array}{|ll|}
\hline \square \text { Chaihuín } & \diamond \text { Oncol } \\
\Delta \text { Laurel } & \boldsymbol{x} \text { Los Boldos } \\
+ \text { Loncoche } & \circ \text { Gualletué } \\
\hline
\end{array}
$$

FIG. 8. Harker diagrams for major elements of arc (Gualletué) and forearc intrusives. Values of each oxide are expressed in weight \%.

\subsection{Source and contamination of the forearc magmas}

The MORB-normalized multi-element diagram for the studied rocks (Fig. 12) shows typical subduction related patterns (calc-alkaline signature, LILE enrichment, HFSE depletion and Nb negative anomaly), which suggests the participation of two components in the genesis of the forearc and arc magmas: the asthenospheric mantle wedge and LILE-rich fluids derived from the subducted plate and/or eroded forearc, which metasomatized the mantle wedge and induced its partial melting (e.g., Iwamori, 1998).

Beneath the forearc, mantle-derived magmas would rise up to the base of the crust, formed by a fossil accretionary prism consisting mainly of siliciclastic meta-sediments and minor metabasite intercalations (e.g., Aguirre et al., 1972; Hervé, 1988; Willner, 2005). Due to density differences, the mantle-derived magmas would stagnate at the base of the fossil (paleo) accretionary prism, forming an assimilation zone in a situation similar to that proposed for the magma evolution in continental magmatic arcs (Hildreth and Moorbath, 1988; Annen et al., 2006). Another possibility is mantle contamination by subduction erosion (Stern, 2011). Such processes would create differentiated and heterogeneous magmas (mainly of granodioritic composition) at regional scale, with fluctuating signals between crustal reservoirs and depleted asthenosphere $(\varepsilon \mathrm{Nd}=+4.24$ to -3.09). Involvement of a MORB-type mantle derived basaltic melts and metasediments has been proposed for the genesis of forearc granitoids, for 

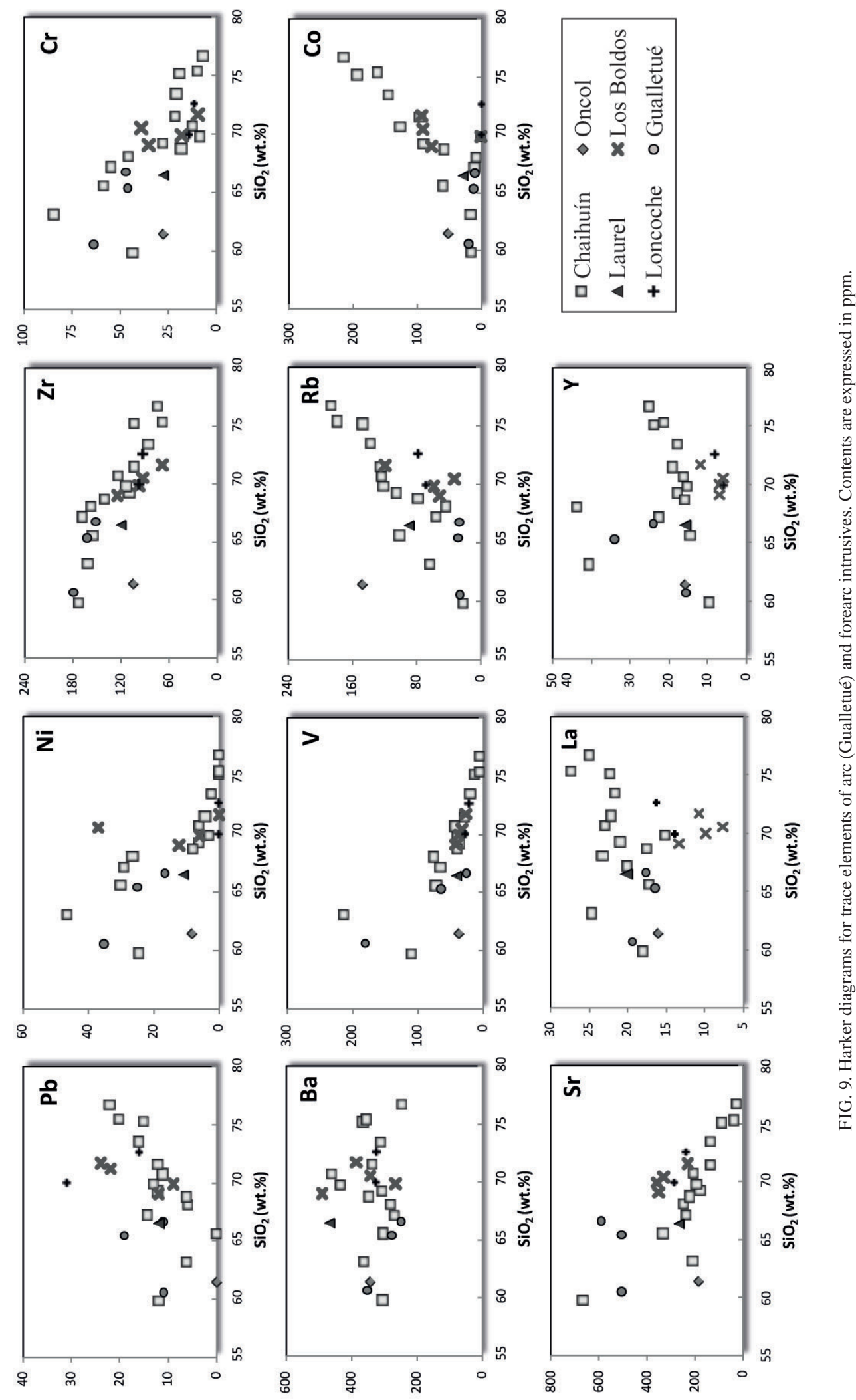

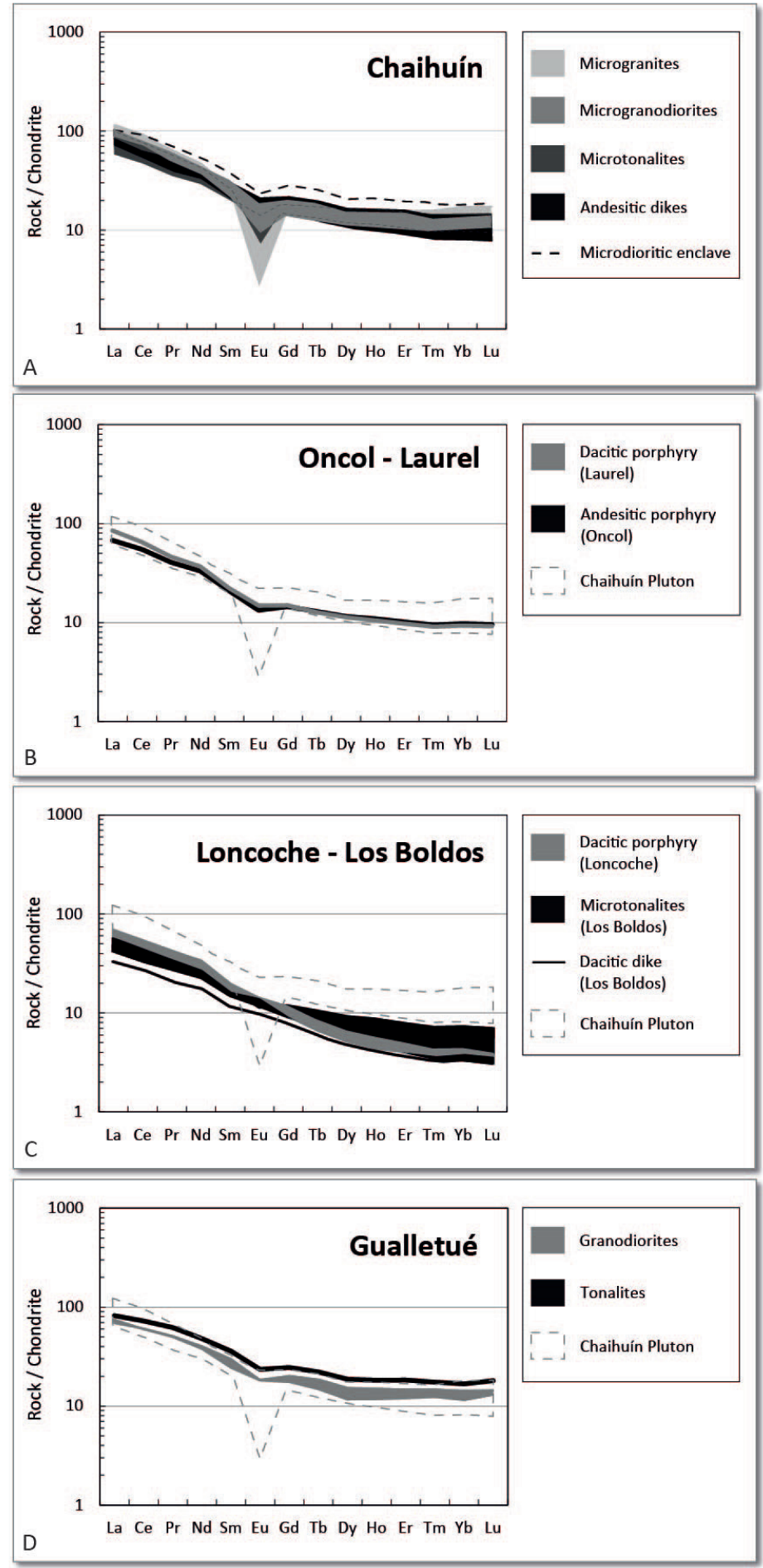

FIG. 10. Chondrite-normalized rare earth elements (REE) diagrams (McDonough and Sun, 1995) of the forearc intrusives: A. Chaihuín Pluton, including the mafic enclave (dotted line, sample Ch-A2) and andesitic dikes. B. Intrusives from Oncol and Laurel, C. Loncoche and Los Boldos. D. Gualletué Plutonic Group, representative of the contemporary arc magmatism. The field of REE patterns of Chaihuin Pluton is showed for the rest of diagrams (grey dotted line). 


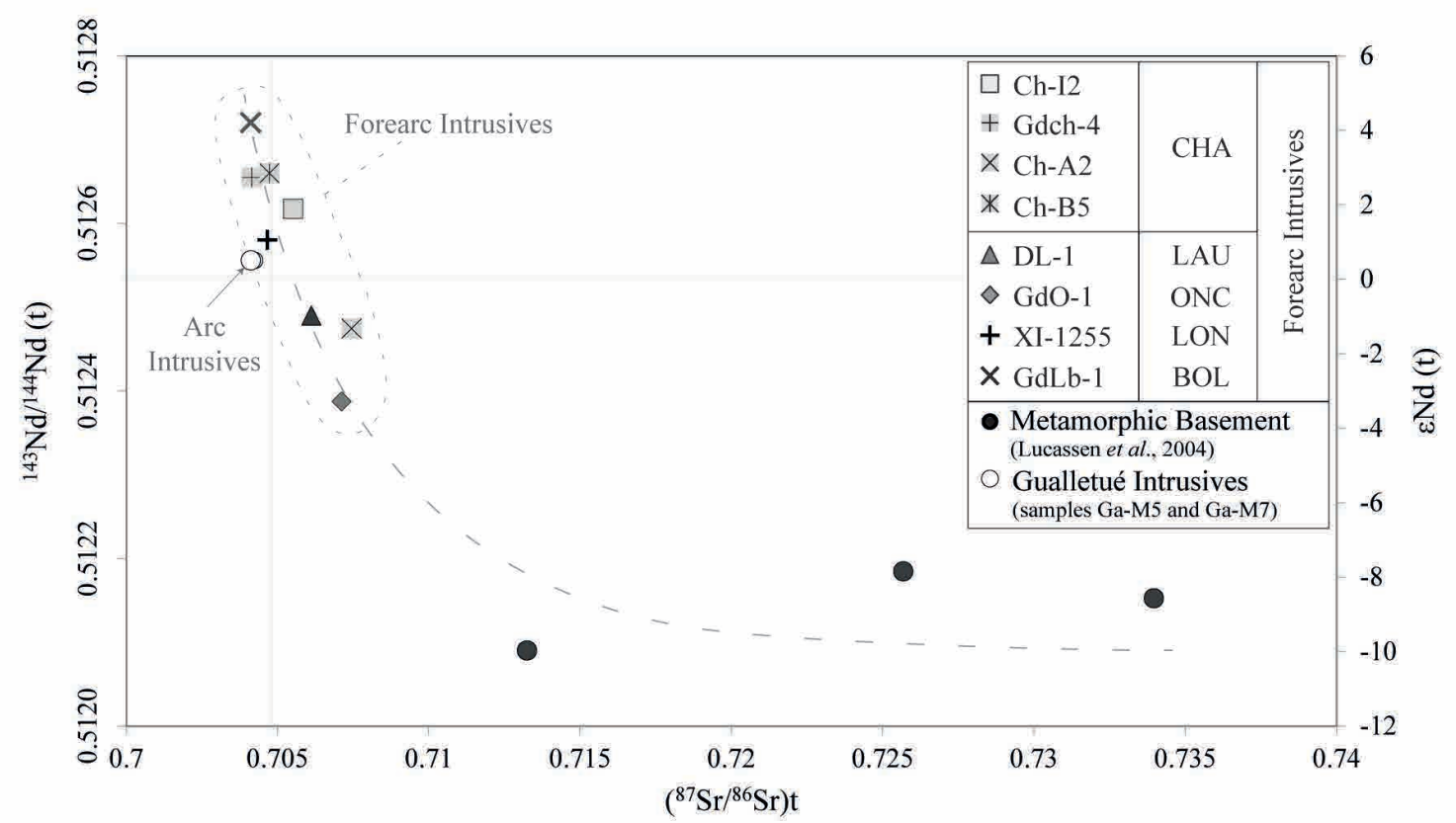

FIG. 11. ${ }^{143} \mathrm{Nd} /{ }^{144} \mathrm{Nd}$ and $\varepsilon \mathrm{Nd}$ versus ${ }^{87} \mathrm{Sr} /{ }^{86} \mathrm{Sr}$ diagram (initials values) for the forearc intrusives (enclosed by dotted line), including data provided by Lucassen et al. (2004) for the Paleozoic-Triassic Metamorphic Basement from the studied area. An hypothetical mixing line (coarser dotted line) is drawn.

TABLE 6. COMPARISON BETWEEN THE STUDIED FOREARC INTRUSIVES NEAR VALDIVIA.

\begin{tabular}{|c|c|c|c|c|c|}
\hline Intrusive & Petrography & $\begin{array}{l}\mathrm{SiO}_{2} \text { range } \\
(\mathrm{wt} \%)\end{array}$ & $\mathbf{L a} / \mathbf{Y b}$ & ${ }^{87} \mathrm{Sr} /{ }^{86} \mathrm{Sr}$ & ${ }^{143} \mathrm{Nd} /{ }^{144} \mathrm{Nd}$ \\
\hline Los Boldos Granitoid & $\begin{array}{l}\text { microtonalites, } \\
\text { microgranodiorites and } \\
\text { microgranites }\end{array}$ & 68.01-70.54 & $9.2-25.0$ & 0.70411 & 0.512744 \\
\hline Loncoche Porphyry & dacitic porphyry & $67.32-70.84$ & 22.4-23.9 & 0.704664 & 0.512582 \\
\hline Laurel Porphyry & dacitic porphyry & 64.56 & 13.5 & 0.706118 & 0.512478 \\
\hline Oncol Porphyry & $\begin{array}{l}\text { dacitic porphyry }+/- \\
\text { andesitic porphyry }\end{array}$ & 59.76 & 10.2 & 0.707116 & 0.512355 \\
\hline Chaihuín Pluton & $\begin{array}{c}\text { porphyritic } \\
\text { microgranodiorites, } \\
\text { microgranites } \pm \\
\text { microtonalites }\end{array}$ & $58.03-76.28$ & 8.7-13.8 & $0.704152-0.70745$ & $0.512455-0.512669$ \\
\hline $\begin{array}{c}\text { Upper Cretaceous } \\
\text { Gualletué Plutonic Group }\end{array}$ & $\begin{array}{l}\text { hornblende quartz-diorite, } \\
\text { biotite tonalite and biotite- } \\
\text { hornblende granodiorite }\end{array}$ & $60.28-66.17$ & 7.1-9.5 & $0.704111-0.704236$ & $0.512715-0.512741$ \\
\hline
\end{tabular}



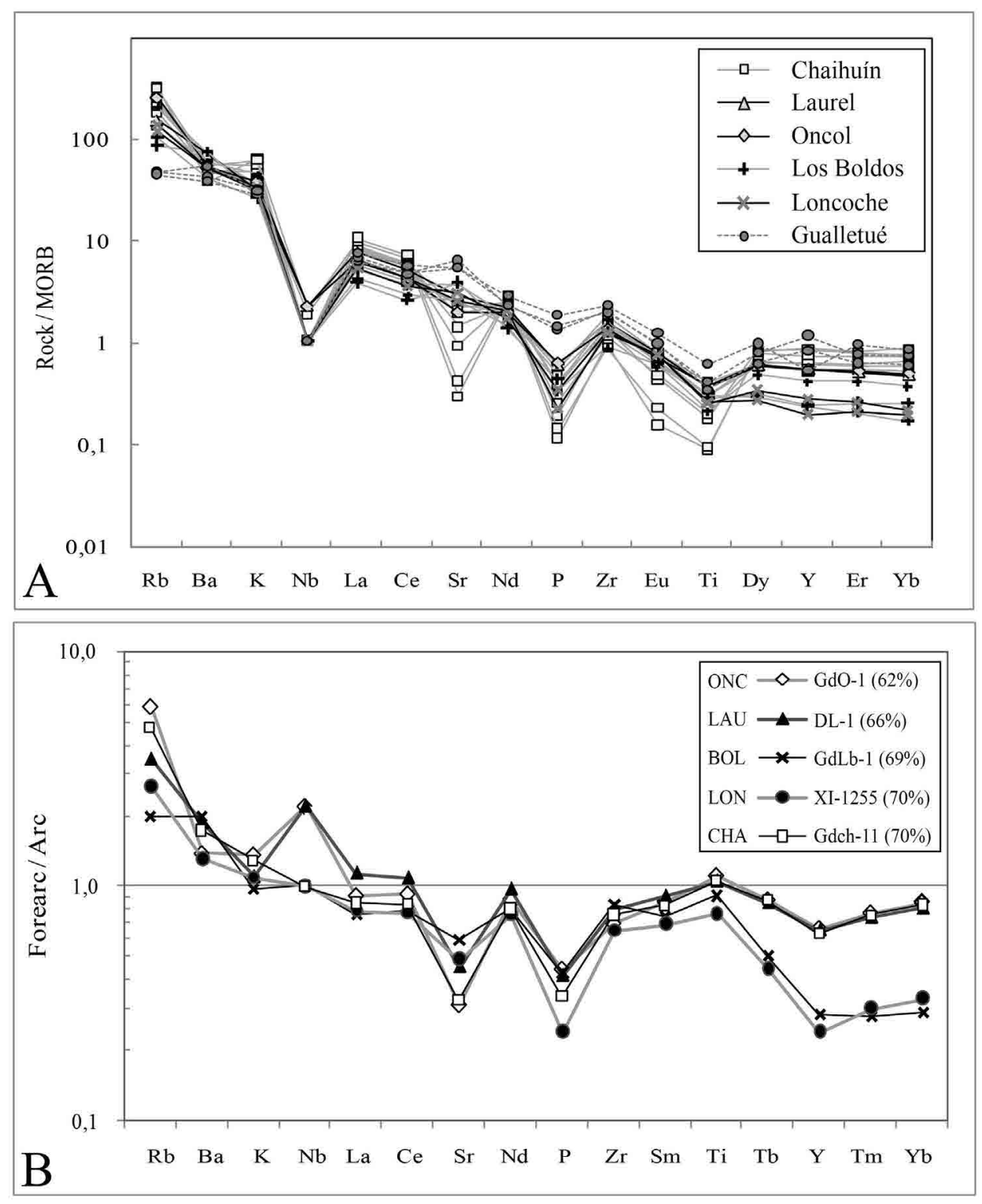

FIG. 12. A. MORB-normalized multi-element diagram (Sun and McDonough, 1989), for Upper Cretaceous forearc and arc (Gualletué) intrusives. B. Multi-element diagram normalized to Ga-M6 sample $\left(\mathrm{SiO}_{2}=67 \%\right)$ from Gualletué Plutonic Group, for the Upper Cretaceous forearc intrusives. The silica content for each sample is indicated in parenthesis next to each sample.

example in the Sanak-Baranof Belt, which intruded into the accretionary prism (Farris, 2010; Ayuso et al., 2009; Sisson et al., 2003).

In the Nd-Sr isotopic diagram (Fig. 11), the coastal granitoids display a narrow isotopic field extending from a MORB-type pole $(\varepsilon N d$ from +4.24 to +1.1$)$ for Los Boldos porphyry, Loncoche dacitic porphyry and Chaihuín pluton to a slightly enriched pole ( $\varepsilon N d$ from -0.94 to -3.1) for Laurel dacitic porphyry, Oncol porphyries and the mafic enclave from Chaihuín. The isotopic data show (Fig. 11) a mixing line between the MORB domain and meta-psammopelites of the accretionary paleo-prism, showing different degrees of assimilation. 
TABLE 7. COMPARISON BETWEEN FOREARC INTRUSIVES NEAR VALDIVIA WITH OTHER FOREARC INTRUSIVES: KODIAK (FARRIS, 2010), CHILE TRIPLE JUNCTION (KAEDING ET AL., 1990).

\begin{tabular}{|c|c|c|c|}
\hline Forearc intrusions & This study & Kodiak (Alaska) & Taitao Peninsula (Chile) \\
\hline Petrography & $\begin{array}{c}\text { Tonalite, granodiorite, } \\
\text { granite }\end{array}$ & $\begin{array}{c}\text { Tonalite, granodiorite, } \\
\text { granite }\end{array}$ & $\begin{array}{c}\text { Tonalite, granodiorite, } \\
\text { granite }\end{array}$ \\
\hline $\mathrm{SiO}_{2}$ range (wt $\%$ ) & $58-76$ & $59-74$ & $62-75$ \\
\hline Aluminum saturation affinity & $\begin{array}{l}\text { Metaluminous to } \\
\text { peraluminous }\end{array}$ & Strongly peraluminous & $\begin{array}{l}\text { Metaluminous to } \\
\text { peraluminous }\end{array}$ \\
\hline $\mathrm{La} / \mathrm{Yb}$ range & $7.1-25$ & $7.5-14.3$ & $5.4-10$ \\
\hline${ }^{87} \mathrm{Sr} /{ }^{86} \mathrm{Sr}$ & $0.704110-0.707116$ & 0.703716-0.706358 & $0.704353-0.704974$ \\
\hline${ }^{143} \mathrm{Nd} /{ }^{144} \mathrm{Nd}$ & $0.512355-0.512744$ & $0.512340-0.512855$ & $0.512707-0.512880$ \\
\hline
\end{tabular}

Contamination of the mantle wedge-derived magmas with continental crust would explain the further LILE enrichment and the more peraluminous nature of the forearc intrusives in comparison to those from Gualletué Plutonic Group. The rather wide ranges of $\mathrm{Pb}$ isotopic composition of the forearc rocks $\left({ }^{206} \mathrm{~Pb} /{ }^{204} \mathrm{~Pb}: 18.57-19.27 ;{ }^{207} \mathrm{~Pb} /{ }^{204} \mathrm{~Pb}\right.$ : $\left.15.62-15.78 ;{ }^{208} \mathrm{~Pb} / 204 \mathrm{~Pb}: 38.50-39.57\right)$, roughly define a scattered linear array in the ${ }^{208} \mathrm{~Pb} /{ }^{204} \mathrm{~Pb}$ versus ${ }^{206} \mathrm{~Pb} /{ }^{204} \mathrm{~Pb}$ diagram; this array extends from the MORB field to high values corresponding to the "Marine Sediments/Upper Crust" (Fig. 13). This confirms the crustal contribution in the genesis of the forearc magmas. Crustal assimilation processes would also occur in shallow magmatic reservoirs, as attested by xenoliths of metamorphic rocks found in the intrusives.

The Loncoche and Los Boldos intrusive rocks ( $\mathrm{SiO}_{2}$ between 67-71 wt\%) have low HREE contents and consequently high $\mathrm{La} / \mathrm{Yb}$ ratios (up to 25), reflecting an apparently adakitic signature as shown in the $\mathrm{Sr} / \mathrm{Y}-\mathrm{Y}$ and $\left(\mathrm{La}_{\mathrm{N}} / \mathrm{Yb}_{\mathrm{N}}\right)$ discrimination diagrams (Drummond and Defant, 1990; Fig. 14). Nevertheless their low Sr contents $(<<400 \mathrm{ppm})$ preclude they are truly adakites.

The microdioritic mafic enclave (Ch-A2) is one of the least evolved rocks of the Chaihuín series (62 wt\% $\mathrm{SiO}_{2}$, with rather high $\mathrm{Ni}$ and $\mathrm{Cr}$ contents comparative to the others rocks) but it has a significantly higher initial ${ }^{87} \mathrm{Sr} /{ }^{86} \mathrm{Sr}$ (0.7075), a negative $\varepsilon N d$ value (-1.1) and high MREE content. These features suggest that mafic enclaves possibly represent the initial pulses of the forearc magmatic event, which could correspond to mantle magmas markedly contaminated by molten material from the fossil accretionary prism.

The andesitic dike (Ch-B5) that cuts the Chaihuín intrusives could have evolved from residual magmas trapped in an independent magma chamber.

\subsection{Fractional crystallization}

The asthenospheric wedge-derived magmas first assimilate crustal material from the fossil accretionary prism, generating magmas of intermediate composition. Mantle heterogeneity and subducted sediments could also play a role in the observed compositional variations. Then, they ascend and differentiate mainly by fractional crystallization. Based on the empirically calibrated geobarometer of the Al-content in hornblende Seifert et al. (2005) estimated the crystallization depth for this forearc intrusives at less than $3 \mathrm{~km}$. This crystallization process resulted in the progressive and gradual mineralogical changes documented in the Chaihuín Pluton.

Amphibole predominates over biotite in the tonalites; the reverse is observed when $\mathrm{SiO}_{2}$ increases, as reflected by the abundant biotite and rare amphibole in late-stage granites. Similarly, the anorthite-content of plagioclase decreases 

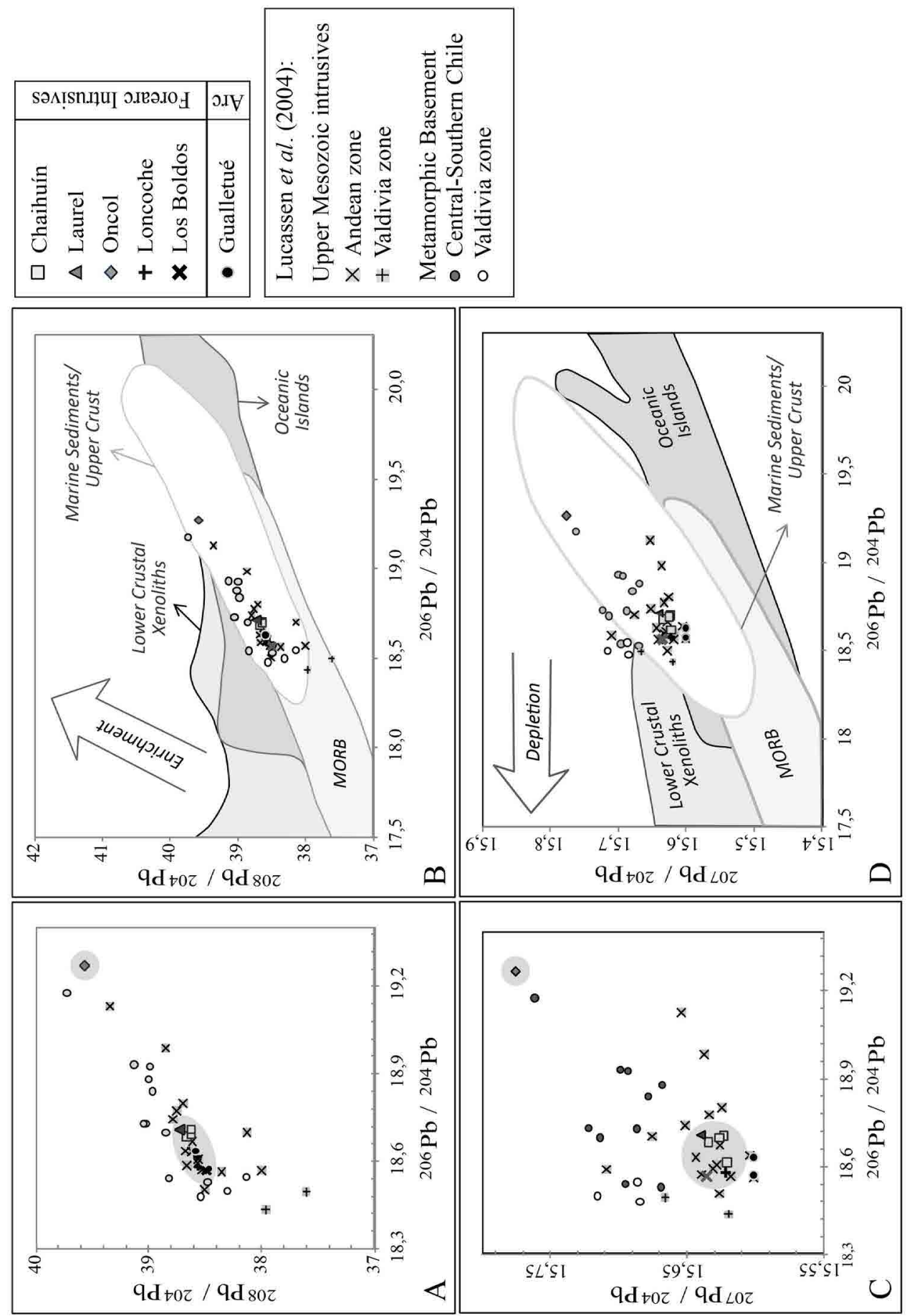

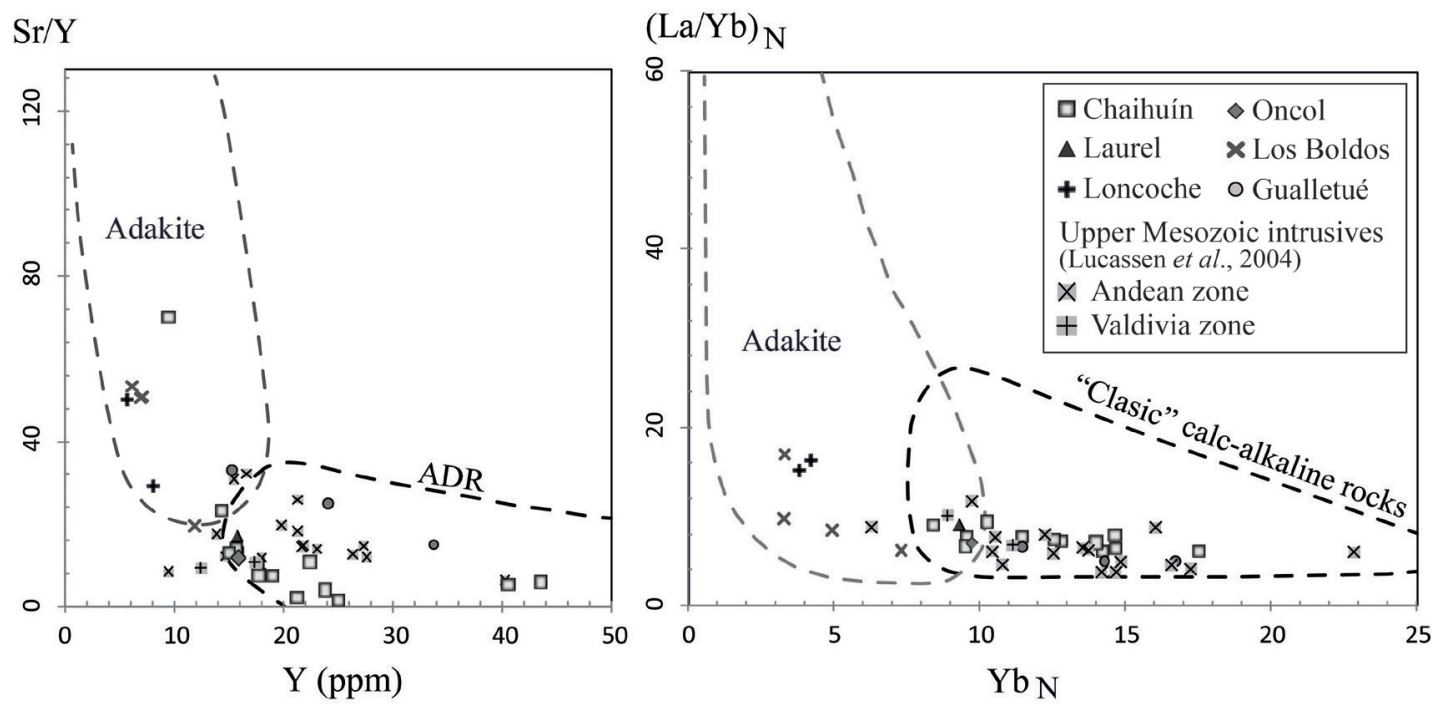

FIG. 14. Discrimination diagrams between adakite versus normal arc rocks (Drummond and Defant, 1990). Data provided by Lucassen et al. (2004) of Upper Mesozoic intrusives from the Andean zone and Valdivia area intrusions are included. A. Sr/Y versus Y diagram where ADR is andesite-dacite-rhyolite (modified from Castillo, 2012). B. (La/Yb) $)_{\mathrm{N}}$ versus $\mathrm{Yb}_{\mathrm{N}}$ diagram (chondrite normalized according to values from McDonough and Sun, 1995); modified from Martin et al. (1999).

progressively with differentiation from $\mathrm{An}_{40}$ in microgranodiorite to $\mathrm{An}_{22}$ in microgranite. On the other hand, Harker diagrams for major, minor and trace elements show generally continuous variation trends with increasing silica content. This is especially well marked for the Chaihuín rocks. These trends suggest the fractionation of the following minerals in agreement with the petrographic observations: plagioclase (decrease of $\mathrm{Al}_{2} \mathrm{O}_{3}, \mathrm{CaO}$, $\mathrm{Sr}$ and $\mathrm{Eu}$ ), amphibole and biotite (decrease of $\mathrm{Fe}_{2} \mathrm{O}_{3}, \mathrm{MgO}$, $\mathrm{MnO}$ and $\mathrm{Al}_{2} \mathrm{O}_{3}$ ), Fe-Ti oxides (decrease of $\mathrm{Fe}_{2} \mathrm{O}_{3}$, $\mathrm{TiO}_{2}, \mathrm{~V}$ ), apatite (decrease of $\mathrm{P}_{2} \mathrm{O}_{5}$ ) and zircon (decrease of $\mathrm{Zr}$ in most differentiated rocks). The spatial distribution of tonalites and microgranites in Chaihuín Pluton suggests that the differentiation occurred from the borders to the center of the intrusion (Fig. 2). Field evidence and fractional crystallization models suggest that the microgranites would be the product of the differentiation of microgranodiorites (Mella et al., 2012).

A progressive enrichment of REEs is observed for Chaihuín rocks (Fig. 10), as well as a deepening of the Eu negative anomaly (related to the fractionation of plagioclase) as the silica content of whole rock increases. A fractional crystallization model has been quantitatively evaluated (using the Rayleigh equation) for the Chaihuín series of rocks based on their REE contents and their modal proportions (Fig. 15). Calculations were performed in two stages: 1) tonalite $(\mathrm{Co}) \rightarrow$ microgranodiorite $(\mathrm{R} 1)$, and 2) microgranodiorite (C'o) $\rightarrow$ microgranite (R'1). For the first stage, the best fit of the calculated curve was obtained for $\mathrm{F}=0.7$ (= fraction of melt remaining after fractional crystallization) with a small discrepancy for the HREE ( $\mathrm{Yb}$ and $\mathrm{Lu}$ ). For the second stage, the calculated curve has good fit for $\mathrm{F}=0.75$, with a discrepancy for $\mathrm{Eu}$.

\subsection{Geotectonic control on the genesis of forearc intrusives}

Forearc areas usually have relatively low heat flow and no- or only minor-magmatic activity (Gill, 1981), due to the depression of the isotherms nearest the trench, as a result of the subduction of the partly cooled oceanic slab beneath the continental plate. However, this scenario can be modified by the interaction of the continental margin with an active oceanic ridge that could be responsible for the magmatic activity in the forearc (e.g., Marshak and Karig, 1977; DeLong et al., 1979; Sisson et al., 2003). In fact, the presence of igneous rocks, either 


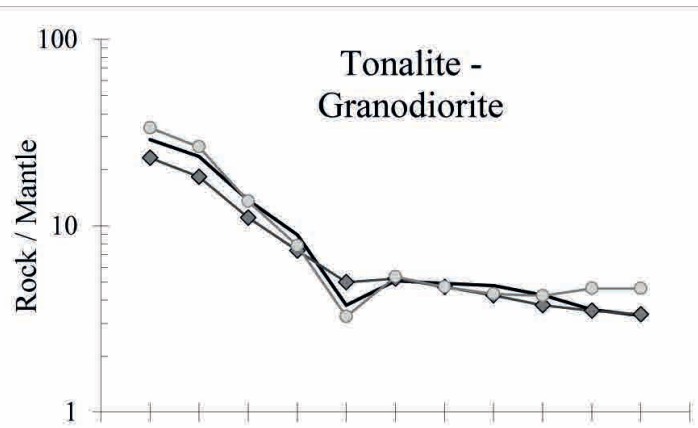

La Ce Nd Sm Eu Gd Tb Dy Er Yb Lu

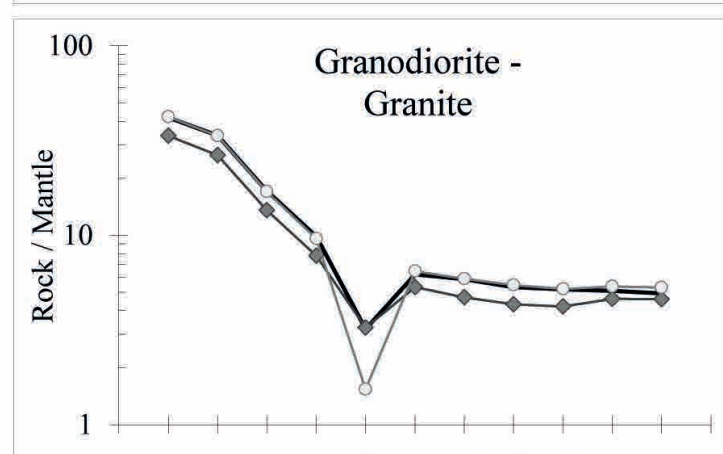

La Ce Nd Sm Eu Gd Tb Dy Er Yb Lu

\begin{tabular}{|c|c|c|c|}
\hline Rock & Tonalite & Granodiorite & Granite \\
\hline Sample & GdCh-11 & GdCh-2 & GdCh-4 \\
\hline Hornblende & 7 & 1 & 0 \\
\hline Biotite & 1 & 6 & 7 \\
\hline Plagioclase & 69.8 & 37 & 15 \\
\hline K Felds. & 2 & 15 & 42.8 \\
\hline Ilmenite & 0.1 & 0.5 & 0.5 \\
\hline Magnetite & 0.1 & 0.5 & 0.5 \\
\hline Quartz & 19.8 & 39.8 & 34 \\
\hline Apatite & 0.1 & 0.1 & 0.1 \\
\hline Zircon & 0.1 & 0.1 & 0.1 \\
\hline Total & 100 & 100 & 100 \\
\hline
\end{tabular}

FIG. 15. Fractional crystallization modeling based on mantle-normalized REE contents (Sun and McDonough, 1989) and modes showed in the adjacent table, for Chaihuín Pluton rocks: Co: parent rock, R1: daughter rock, L1: calculated daughter rock. The modeling was performed in two stages: tonalite $\rightarrow$ granodiorite (at the top) and granodiorite $\rightarrow$ granite (at the bottom). Partition coefficients were taken from Rollinson (1993).

volcanic (basalts to dacites) or plutonic (tonalites to granites) in such position has been used as a key indicator of plate redistribution in converging margins (Groome et al., 2003).

Between Cretaceous and Early Eocene, Farallon and Aluk (or Phoenix) plates subducted beneath South America (Fig. 16A). The triple junction (FarallonAluk- South American) would have migrated to the south from the northern edge of South America (Folguera and Ramos, 2002), to be positioned in the trench at northern Chile $\left(\sim 18^{\circ} \mathrm{S}\right)$ in the Cretaceous ( 140-120 Ma, Müller et al., 2008; Somoza and Ghidella, 2012). Subsequently, the triple junction would have moved south along the Chilean edge until it finally arrived to the Patagonian Andes latitudes in the Paleogene ( $42 \mathrm{Ma}$, Folguera and Ramos, 2002; 50 Ma, Müller et al., 2008; Breitsprecher and Thorkelson, 2009; Scalabrino et al., 2009; 45 Ma, Somoza and Ghidella, 2012; $60 \mathrm{Ma}$, Seton et al., 2012). However, the exact chronology of the migration of the triple junction from northern Chile to Patagonia is still undetermined. On the other hand, a new geotectonic reconstruction (Seton et al., 2012; Müller et al., 2016) indicates the fracture of the Aluk plate about 120 Ma ago into four plates: Hikurangi, Manihiki, Chazca and Catequil; the latter two being the only ones that subducted beneath South America (Fig. 16A). Although the model of Müller et al. (2016) shows a more complex pattern described by the Catequil-Chazca ridge along the South America border, it also indicates the presence of an active spreading center at the considered latitudes during the range between 100-70 Ma.

This is in agreement with the age of the studied intrusions of the Costal Range near Valdivia and it is therefore possible to attribute the origin of the magmatic activity to a thermal anomaly in the forearc region produced by subduction of an 


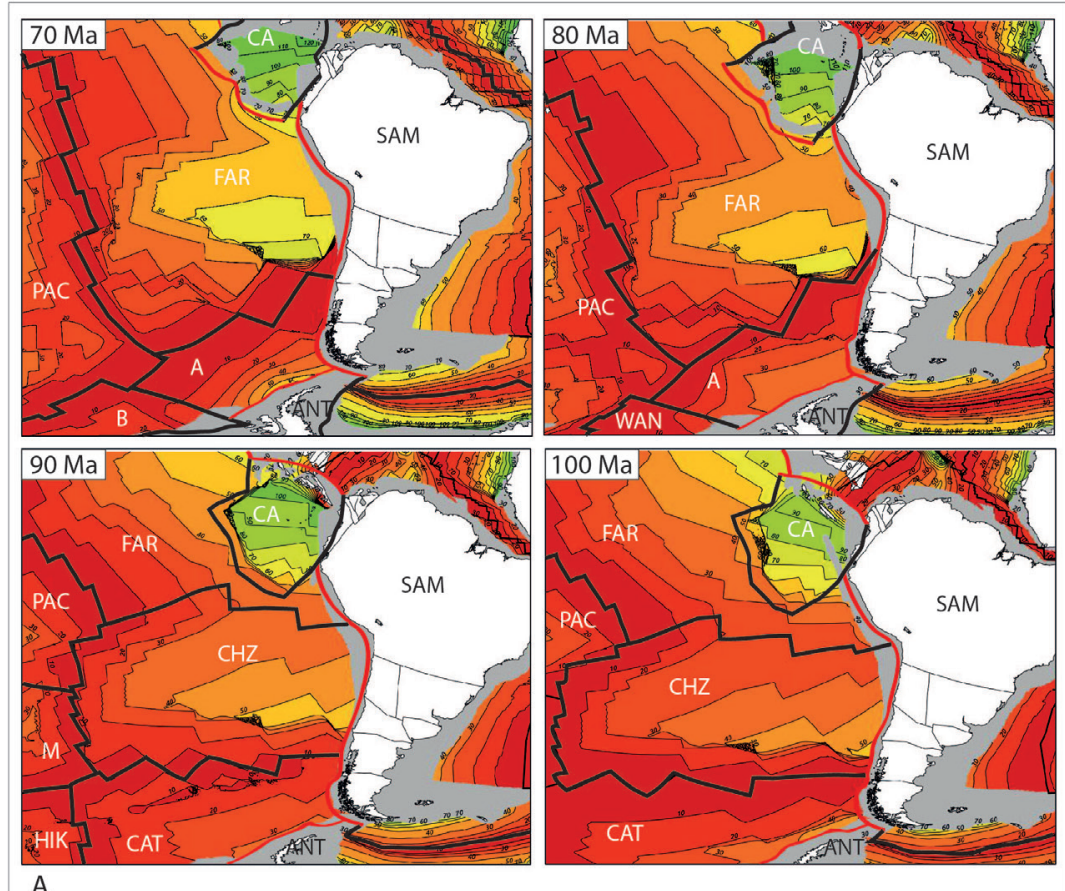

A

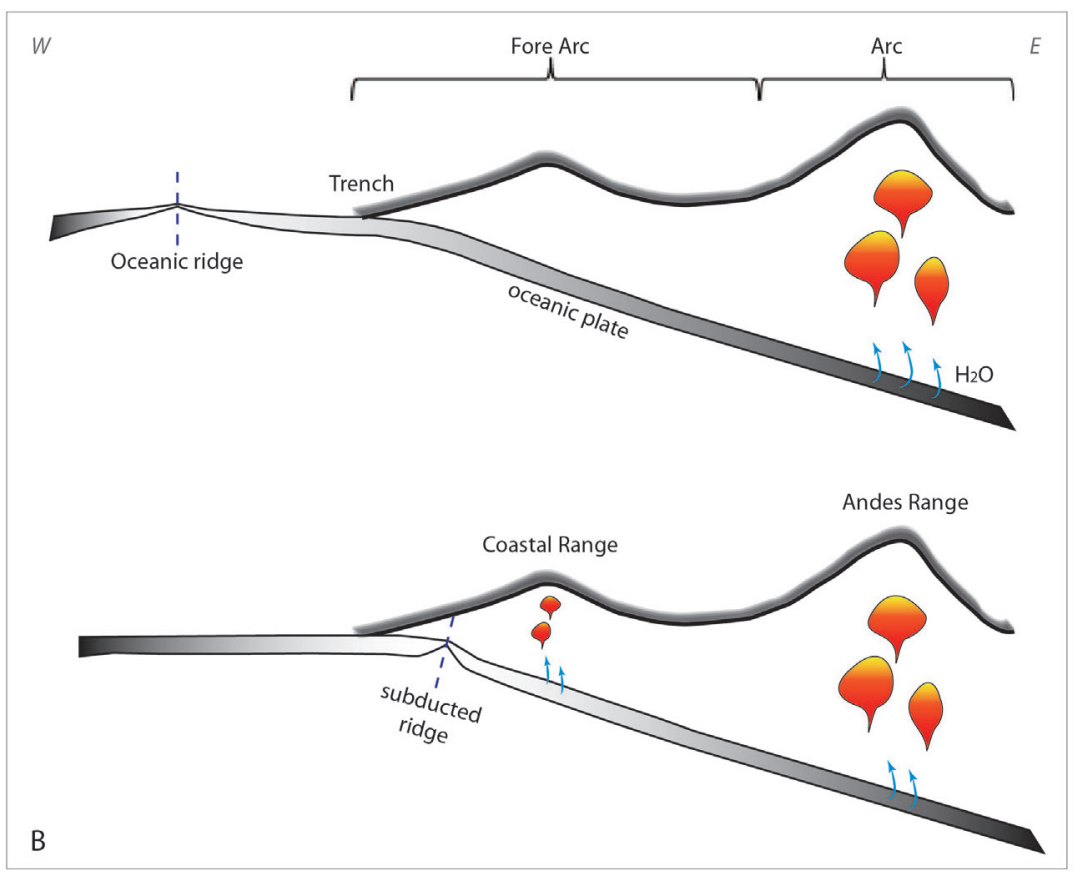

FIG. 16. A. Paleotectonic setting at South American western edge for the period 100-70 Ma. Plates abbreviations: CA: Caribbean; FAR: Farallon; SAM: South American; PAC: Pacific; A: Aluk; B: Bellingshausen; ANT: Antarctic; WAN: West Antarctic; CHZ: Chasca; CAT: Catequil; M: Manihiki Plateau; HIK: Hikurangi. Tectonic plate reconstruction was made by Felipe Quiero, modified from Müller et al. (2016), using the free software GPlates: http://www.gplates.org. B. Schematic section showing arc and forearc zones in a "normal configuration" (at the top), far away from an oceanic ridge; and a "special stage" with forearc zone perturbed by a thermal anomaly given by the ridge subduction (at the bottom), as likely occurred at Upper Cretaceous times. Based on Müller et al. (2016) model. 
oceanic ridge, as proposed by Glodny et al. (2006). Nevertheless, in the plate reconstruction of Müller et al. (2016, Fig. 16A) it is observed that the Farallon plate did not migrate to Patagonia. Instead, the triple junction Chazca-Catequil-South America migrates from the south to the north (compare 100 and $70 \mathrm{Ma}$ reconstructions from figure 16A).

The subduction of an oceanic ridge involves the generation of a slab window (Dickinson and Snyder, 1979; Thorkelson, 1996), which could explain the decreasing activity of the arc magmatism or its replacement by a MORB-like or rift-type volcanism. The latter anomalous magmatism has not been observed in the arc rocks that are contemporaneous with the studied intrusions: indeed these arc rocks typically have a calc-alkaline signature. The lack of attenuation of the magmatic activity in the arc and the calc-alkaline signature of the forearc rocks are not in favour of the development of a slab window. This could be explained by the presence of a ridge with strongly oblique subduction to the trench which does not allow the development of a large slab window (Fig. 16B).

The subduction of a young and hot oceanic crust expectable in a ridge subduction environment would generate slab dehydration at areas near the trench, which would allow the mantle melting beneath the forearc, as suggested by Iwamori (1998). Therefore, slab dehydration would have been developed during the Upper Cretaceous, simultaneously under both forearc and arc regions (Fig. 16B).

\subsection{Geodynamic implications for the Andean margin}

The knowledge of the configuration, ages and position of the ridge segments subduction beneath the south-western South American continent during the Upper Cretaceous is still in progress. Glodny et al. (2006) proposed that the origin of the forearc intrusives near Valdivia was the north-south passage of Farallon-Aluk oceanic ridge, which created a thermal anomaly. But if we consider the new plate reconstruction (Müller et al., 2016) this forearc magmatism should be related to the passage of the Chazca-Catequil-South America triple junction. In any case, the results of this work can be used to refine paleotectonics reconstruction, specifying the presence of active ocean ridge segments interacting with western South America at $c a .39^{\circ}$ $40^{\circ} \mathrm{S}$ during the 100-70 Ma period.

Considering the migration of the Farallon-AlukSouth America triple junction, we would expect to find forearc intrusions with progressively decreasing ages from the north (Loncoche and Los Boldos intrusives) to the south (Chaihuín Pluton). To the south of the studied zone, on Chiloé Island $\left(42^{\circ} \mathrm{S}\right)$ there are small and isolated sub-volcanic bodies of Eocene age (Metalqui granodioritic pluton: 39.6 $\pm \quad 0.3 \mathrm{Ma}$, and Gamboa Dacite, of 37.2 \pm 1.2 Ma; Duhart and Adriasola, 2008) in the forearc area, which could account for the migration of the ridge to the south. However, zircon and apatite fission track studies in Paleozoic-Triassic metamorphic rocks of Chiloé suggest the existence of a thermal anomaly between $\sim 110$ and $70 \mathrm{Ma}$ (Glodny et al., 2007; Thomson and Hervé, 2002), that is much earlier than the Paleogene igneous activity. Therefore, the magmatic bodies of Chiloé could be linked to a subsequent subduction episode, either from another segment of the ridge or from a different expansion system. In contrast, to the north of the studied area, forearc intrusions older than the Upper Cretaceous have not been reported. This could be attributed to a rapid advance of the ridge along northern latitudes (that never generated forearc magmatism), or, if they have ever existed, they are now hidden beneath the seafloor or they were eroded by subduction. The fact such a large area (from Valdivia to Chiloé) seemed to be thermally perturbed during the same period of time can be related to the geometry and configuration of the oceanic ridge: likely with parallel direction with respect to western border of South America (Fig. 16B), or it corresponds to the subduction of different segments of the ridge at different latitudes of the continental margin.

\section{Conclusions}

The Upper Cretaceous magmatic bodies of the Costal Range, in the Valdivia area, are in forearc position with respect to the contemporaneous magmatic arc located about $100 \mathrm{~km}$ to the East. Several intrusions were studied, the most representative being which consists mainly of granodiorites and granites the Chaihuín Pluton.

The forearc intrusive event in the Valdivia area is considered as anomalous in the converging margin dynamics of the Andes: it is indeed not linked to normal subduction processes; nevertheless, it displays typical calc-alkaline signature (AFM trend, LILE enrichment, negative $\mathrm{Nb}$ anomaly). Compared to the Gualletué Plutonic Group, which is representative of the contemporary arc magmatism, the forearc 
intrusions present some differences: their emplacement level, more peraluminous nature, LILE enrichment, relative depletion in HFSE, REE patterns and their more variable and more enriched $\mathrm{Sr}$ and $\mathrm{Nd}$ isotopic compositions.

The forearc intrusions were emplaced at shallow level (epizonal conditions). They dominantly consist of tonalites-microgranodiorites-microgranites with porphyritic textures; their composition is predominantly felsic $\left(60<\mathrm{SiO}_{2}<77 \%\right)$. The $\mathrm{Sr}$ and $\mathrm{Nd}$ isotopic compositions suggest the involvement of two components in the genesis of their parental magmas: a MORB-like depleted mantle and an enriched crustal component presumably the metasedimentary rocks of the Late Paleozoic-Triassic accretionary prism (Bahía Mansa Metamorphic Complex). Mantle melting was initially triggered by fluids derived from the slab dehydration; the generated magma would be mafic, hydrated and isotopically depleted. During its uprise, the magma would have stayed at the base of the accretionary prism and induced partial melting or assimilation of metasedimentay material, producing a more siliceous and isotopically more rediogenic, contaminated magma. Alternatively, contamination could result from subduction erosion. While further uprising, the contaminated magmas differentiated by fractional crystallization which gave rise to the compositional diversity of the studied plutons (from quartz diorite to granite).

The origin of the parental magma(s) of the investigated forearc intrusions is attributed to a thermal anomaly in the forearc related to the subduction of an active ridge beneath the South American continent; this ridge was thought to be the Farallon-Aluk-South American triple junction (Glodny et al. 2006), but new reconstruction (Seton et al., 2012; Müller et al., 2016) suggest instead the Chazca-Catequil-South American triple junction migration.

The studied forearc intrusives could tentatively be interpreted as reflecting the presence of an active oceanic ridge in the South American edge between $39^{\circ}$ and $40^{\circ} \mathrm{S}$, at around $100-70 \mathrm{Ma}$.

Severals intrusiones were estudied, the most representative being the Chaihuín Pluton with consists mainly of granodiorites and granites.

\section{Acknowledgements}

This work is part of the cooperation work between the University of Concepción and Sernageomin. Authors thank the Puerto Varas Technical Office and Sernageomin for its logistic and laboratory support. Authors also thank the support of the Research Board of the University of Concepción (Project Diuc No 209.025.035-1.0) and the efficient field collaboration of P. Rodríguez and E. Inostroza. We are grateful to M. Calderón, P. Vásquez and the editor W. Vivallo, whose comments and suggestions improve this work. We are also grateful to Peter Lewis (VRID, Udec) for his first translation, Dr. A. Tassara for constructive comments on earlier version of this paper and F. Quiero for his support on plate reconstructions.

\section{References}

Aguirre, L.; Hervé, F.; Godoy, E. 1972. Distribution of metamorphic facies in Chile-An Outline. Krystalinikum 9: 7-19.

Anma, R.; Armstrong, R.; Orihashi, Y.; Ike, S-I.; Shin, K.-C.; Kon, Y.; Komiya, T.; Ota, T.; Kagashima, S-I.; Shibuya, T.; Yamamoto, S.; Voloso, E.; Fanning, M.; Hervé, F. 2009. Are the Taitao granites formed due to the subduction of the Chile ridge? Lithos 113: 246-258.

Annen, C.; Blundy, J.D.; Sparks, R.S.J. 2006. The genesis of intermediate and silicic magmas in deep crustal hot zone. Journal of Petrology 47: 505-539.

Arenas, M.; Jara, C.; Milovic, J.; Pérez, Y.; Behlau, J.; Hanisch, J.; Helms, F. 2005. Geología para el ordenamiento territorial: área de Valdivia, Región de Los Lagos. Servicio Nacional de Geología y Minería, Carta Geológica de Chile, Serie Geología Ambiental 8: 71 p. Mapa 1: Base Geológica, escala 1:100.000. Santiago.

Ashwal, L.D.; Demaiffe, D.; Torsvik, T.H. 2002. Petrogenesis of the Neoproterozoic granitoids and related rocks from the Seychelles: the case for an Andean-Type origin. Journal of Petrology 43: 45-83.

Ayuso, R.A.; Haeussler, P.J.; Bradley, D.C.; David, W.; Farris, D.W.; Foley, N.K.; Wandless, G.A. 2009. The role of ridge subduction in determining the geochemistry and Nd-Sr-Pb isotopic evolution of the Kodiak batholith in southern Alaska. Tectonophysics 464: 137-163.

Babarin, B.; Didier, J. 1992. Genesis and evolution of mafic microgranular enclaves through various types of interaction between coexisting felsic an mafic magmas. Transactions of the Royal Society Edinburgh: Earth Sciences 83: 145-153.

Breitsprecher, K.; Thorkelson, D.J. 2009. Neogene kinematic history of Nazca-Antarctic-Phoenix slab windows beneath Patagonia and the Antarctic Peninsula. Tectonophysics 464: 10-20. 
Castillo, P.R. 2012. Adakite petrogenesis. Lithos 134: 304-316.

Creixell, C.; Oliveros, V.; Vásquez, P.; Navarro, J.; Vallejos, D.; Valin, X.; Godoy, E.; Ducea, M.N. 2016. Geodynamics of Late Carboniferous-Early Permian forearc in north Chile (28 $30^{\prime}-29^{\circ} 30^{\prime}$ S). Journal of the Geological Society 173: 757-772.

DeLong, S.E.; Schwarz, W.M.; Anderson, R.N.1979. Thermal effects of ridge subduction. Earth and Planetary Science Letters 44: 239-246.

Dickinson, W.R.; Snyder, W.S. 1979. Geometry of subducted slabs related to San Andreas transform. Journal of Geology 87: 609-627.

Drummond, M.S.; Defant, M.J. 1990. A model for trondhjemite-tonalite-dacite genesis and crustal growth via slab melting: Archaean to modern comparisons. Journal of Geophysical Research 95: 21503-21521.

Duhart, P.; McDonough, M.; Muñoz, J.; Martin, M.; Villeneuve, M. 2001. El Complejo Metamórfico Bahía Mansa en la Cordillera de la Costa del centrosur de Chile (39³0’-4200’ S): geocronología K-Ar, ${ }^{40} \mathrm{Ar} /{ }^{39} \mathrm{Ar}$ y U-Pb e implicancias en la evolución del margen sur-occidental de Gondwana. Revista Geológica de Chile 28 (2): 179-208. doi: 10.5027/ andgeoV28n2-a03.

Duhart, P.; Martin, M.; Muñoz, J.; Crignola, P.; McDonough, M. 1997. Acerca de la edad del Protolito del Basamento Metamórfico de la Cordillera de la Costa de la $\mathrm{X}^{\mathrm{a}}$ Región: edades preliminares ${ }^{207} \mathrm{~Pb} /{ }^{206} \mathrm{~Pb}$ en circones detríticos. In Congreso Geológico Chileno, No. 8, Actas 2: 1267-1270. Antofagasta.

Duhart, P.; Adriasola, A.C. 2008. New time-constraints on provenance, metamorphism and exhumation of the Bahía Mansa Metamorphic Complex on the Main Chiloé Island, south-central Chile. Revista Geológica de Chile 35 (1): 79-104. doi: 10.5027/ andgeoV35n1-a04.

Farris, D.W. 2010. Tectonic and petrologic evolution of the Kodiak batholith and the trenchward belt, Kodiak Island, AK: Contact fault juxtaposition? Journal of Geophysical Research 115: B07208.

Folguera, A.; Ramos, V.A. 2002. Los efectos producidos por la aproximación,colisión y subducción de dorsales pacíficas en los Andes Patagónicos. Acta Geológica Hispánica 37 (4): 329-353.

Forsythe, R.D.; Nelson, E.P.; Carr, M.J.; Kaeding, M.E.; Hervé, M.; Mpodozis, C.; Soffia, J.M.; Harambour, S. 1986. Pliocene near-trench magmatism in southern Chile: a possible manifestation of ridge collision. Geology 14: 23-27.
Gill, J.B. 1981. Orogenic andesites and plate tectonics. Springer-Verlag: 401 p. Germany.

Glodny, J.; Lohrmann, J.; Echtler, H.; Gräfe, K.; Seifert, W.; Collao, S.; Figueroa, O. 2005. Internal dynamics of a paleoaccretionary wedge: insights from combined isotope tectonochronology and sandbox modelling of the South-Central Chilean forearc. Earth and Planetary Science Letters 231: 23-39.

Glodny, J.; Echtler, H.; Figueroa, O.; Franz, G.; Gräfe, K.; Kemnitz, H.; Kramer, W.; Krawczyk, C.; Lohrmann, J.; Lucassen, F.; Melnik, D.; Rosenau, M.; Seifert W. 2006. Long-Term Geological Evolution and mass-flow balance of the South-Central Andes. In The Andes: active subduction orogeny (Oncken, O.; Chong, G.; Franz, G.; Giese, P.; Götze, H.-J.; Ramos, V.A.; Strecker, M.R.; Wigger, P.; editors). Springer: 401-428. Germany.

Glodny, J.; Gräfe, K.; Echtler, H.; Rosenau, M. 2007. Mesozoic to Quaternary continental margin dynamics in South-Central Chile $\left(36^{\circ}-42^{\circ} \mathrm{S}\right)$ : the apatite and zircon fission track perspective. International Journal of Earth Sciences (Geol. Rundsch) 97: 1271-1291. doi: 10.1007/s00531-007-0203-1.

Groome, W.; Thorkelson, D.; Friedman, R.; Mortensen, J.; Massey, N.; Marshall, D; Layer, P. 2003. Magmatic and tectonic history of the Leech River Complex, Vancouver Island, British Columbia: Evidence for ridge-trench intersection and accretion of the Crescent Terrane. In Geology of a transpressional orogen developed during ridge-trench interaction along the North Pacific marginmargin (Sisson, V.B.; Roeske, S.M.; Pavlis, T.L.; editors). Geological Society of America, Special Paper 371: 327-353. Boulder.

Guivel, C.; Lagabrielle, Y.; Bourgois, J.; Hervé, M.; Arnaud, N.; Fourcade, S.; Cotten, J.; Maury, R. 2003. Very shallow melting of oceanic crust during spreading ridge subduction: Origin of near-trench Quaternary volcanism at the Chile Triple Junction. Journal of Geophysical Research 108 (B7): 2345. doi:10.1029/2002JB002119.

Hervé, F. 1988. Late Paleozoic subduction and accretion in Southern Chile. Episodes 11: 183-188.

Hervé, F.; Calderón, M.; Fanning, C.M.; Pankhurst, R.J.; Godoy, E. 2013. Provenance variations in the Late Paleozoic accretionary complex of central Chile as indicated by detrital zircons. Gondwana Research 23: 1122-1135.

Hildreth, W.; Moorbath, S. 1988. Crustal contributions to arc magmatism in the Andes of central Chile. Contribution to Mineralogy and Petrology 98: 455-489 
IIG/MMAJ/JICA. 1978. Informe de reconocimiento geológico del área Coihueco-Ñuble-Lonquimay, Central sur de Chile, Fase III. Instituto de Investigaciones Geológicas 1: 335 p. Santiago.

Illies, H. 1970. Geología de los alrededores de Valdivia y volcanismo y tectónica en márgenes del Pacífico de Chile Meridional. Instituto de Geología y Geografía, Universidad Austral de Chile: 64 p. Valdivia.

Irvine, T.; Baragar, W. 1971. A guide to the chemical classification of the common volcanic rocks. Canadian Journal of Earth Sciences 8: 523-548.

Iwamori, H. 1998. Transportation of $\mathrm{H}_{2} \mathrm{O}$ and melting in subduction zones. Earth and Planetary Science Letters 160: 65-80.

Kaeding, M.; Forsythe, R.D.; Nelson, E.P. 1990. Geochemistry of the Taitao ophiolite and near-trench intrusions from the Chile Margin Triple Junction. Journal of South America Earth Sciences 3: 161-177.

Lara, L.; Moreno, H. 2004. Geología del área LiquiñeNeltume, regiones de La Araucanía y de Los Lagos, Escala 1:100.000. Servicio Nacional de Geología y Minería, Carta Geológica de Chile, Serie Geología Básica 83: 23 p., 1 mapa escala 1:100.000. Santiago.

Lucassen, F.; Trumbull, R.; Franz, G.; Creixell, C.; Vásquez, P.; Romer, R.L.; Figueroa, O. 2004. Distinguishing crustal recycling and juvenile additions at active continental margins: the Paleozoic to recent compositional evolution of the Chilean Pacific margin (36-41 ${ }^{\circ} \mathrm{S}$ ). Journal of South American Earth Sciences 17: 103-119.

Madsen, J.K.; Thorkelson, D.J.; Friedman, R.M.; Marshall, D.D. 2006. Cenozoic to Recent plate configurations in the Pacific Basin: Ridge, subduction and slab window magmatism in western North America. Geosphere 2 (1): 11-34. doi: 10.1130/GES00020.1.

Marshak, R.S.; Karig, D.E. 1977. Triple junctions as a cause for anomalous near-trench activity between the trench and volcanic arc. Geology 5: 233-236.

Martin, M. 1996. Report on U-Pb geochronology conducted at the Isotope Geochemistry Laboratory, University of Kansas, between June 17 and August 30, 1996, on samples collected for the Decima Norte project. Informe (Inédito), Servicio Nacional de Geología y Minería: 41p.

Martin, M.; Kato, T.; Rodríguez, C.; Godoy, E.; Duhart, P.; McDonough, M.; Campos, A. 1999. Evolution of the late Paleozoic accretionary complex and overlying forearc-magmatic arc, south central Chile $\left(38^{\circ}-41^{\circ} \mathrm{S}\right)$ : Constrains for the tectonic setting along the southwestern margin of Gondwana. Tectonics 18: 582-605.

Martínez, R.; Pino, M. 1979. Edad, paleoecología y sedimentología del Mioceno marino de la Cuesta
Santo Domingo, Provincia de Valdivia, X Región. In Congreso Geológico Chileno, No. 2, Actas 2: 103-124. Arica.

McDonough, W.F.; Sun, S.S. 1995. The composition of the Earth. Chemical geology 120: 223-253.

Mella, M.; Duhart, P.; McDonough, M.; Antinao, JL.; Elgueta, S.; Crignola, P. 2012. Geología del Área Valdivia-Corral. Servicio Nacional de Geología y Minería, Carta Geológica de Chile, Serie Geología Básica 137: 49 p., 1 mapa escala 1:100.000. Santiago. Moreno, H.; Lara, L. 2008. Geología del área PucónCurarrehue, regiones de La Araucanía y de Los Ríos. Servicio Nacional de Geología y Minería, Carta Geológica de Chile, Serie Geología Básica 115: 36 p., 1 mapa escala 1:100.000. Santiago.

Müller, R.D.; Seton, M.; Zahirovic, S.; Williams, S.; Matthews, K.; Wright, N.; Shephard, G.; Maloney, K.; Barnett-Moore, N.; Hosseinpour, M.; Bower, D.; Cannon, J. 2016. Ocean Basin Evolution and GlobalScale Plate Reorganization Events Since Pangea Breakup. Annual Rewiew of Earth and Planetary Sciences 44: 107-138.

Müller, R.D.; Sdrolias, M.; Gaina, C.; Steinberger, B.; Heine, C. 2008. Long-Term Sea-Level Fluctuations Driven by Ocean Basin Dynamics. Science 319: 13571362. doi: 10.1126/science. 1151540.

Munizaga, F.; Hervé, F.; Drake, R.; Pankhurst, R.J.; Brook, M.; Snelling, N. 1988. Geochronology of the Lake Region of south-central Chile $\left(39^{\circ}-42^{\circ} \mathrm{S}\right)$ : Preliminary results. Journal of South American Earth Sciences 1: 309-316.

Muñoz, J.; Troncoso, R.; Duhart, P.; Criñola, P.; Farmer, L.; Stern, C.R. 2000. The relation of the mid-Tertiary coastal magmatic belt in south-central Chile to the late Oligocene increase in plate convergence rate. Revista Geológica de Chile 27 (2): 177-204. doi: 10.5027/ andgeoV27n2-a03.

Muñoz J.; Troncoso, R.; Stern, C. 2007. The Longitudinal Depression and Coastal Cordillera late Oligoceneearly Miocene volcanism (37-44 ${ }^{\circ}$ S). In The Geology of Chile (Moreno, T.; Gibbons, W.; editors). The Geological Society of London Publishing House: 496 p. United Kingdown.

Quiroz, D.; Duhart, P.; Crignola, P. 2007. Geología del Área Lanco-Loncoche. Regiones de La Araucanía y de Los Ríos. Servicio Nacional de Geología y Minería, Carta Geológica de Chile, Serie Geología Básica 106: 21 p., 1 mapa escala 1:100.000. Santiago.

Rollinson, H. 1993. Using geochemical data: evaluation, presentation, interpretation. Longman Group: 352 p. UK. 
Scalabrino, B.; Lagabrielle, Y.; de la Rupelle, A.; Malavieille, J.; Polvé, M.; Espinoza, F.; Morata, D.; Suárez, M. 2009. Subduction of an Active Spreading Ridge Beneath Southern South America: A Review of the Cenozoic Geological Records from the Andean Foreland, Central Patagonia (46-47º ). In Subduction Zone Geodynamics (Lallemand, S.; Funiciello, F.; editors). Springer-Verlag Berlin Heidelberg: 227-246. Berlin.

Seifert, W.; Rosenau, M.; Echtler, H. 2005. Crystallization depths of granitoids of South Central Chile estimated by Al-in-hornblende geobarometry: implications for mass transfer processes along the active continental margin. Neues Jahrbuch für Geologie und PaläontologieAbhandlungen 236: 115-127.

Sernageomin. 1998. Estudio Geológico-Económico de la X ${ }^{a}$ Región Norte. Servicio Nacional de Geología y Minería, Informe Registrado IR-98-15, 6 Vols., 27 mapas a diferentes escalas. Santiago.

Sernageomin. 2004. Mapa Geológico de Chile: Versión digital, Escala 1:1.000.000. Publicación Geológica Digital 7: 1 CD-ROM, versión 1.0. Santiago, Chile.

Seton, M.; Müller, R.D.; Zahirovic, S.; Gaina, C.; Torsvik, T.; Shephard, G.; Talsma, A.; Gurnis, M.; Turner, M.; Maus, S.; Chandler, M. 2012. Global continental and ocean basin recostructions since 200 Ma. EarthScience reviews 113: 212-270.

Shand, S. 1927. Eruptive Rocks. John Wiley and Sons: 360 p. Nueva York.

Sisson, V.B.; Pavlis, T.L.; Roeske, S.M.: Thorkelson, D.J. 2003. Introduction: an overview of ridge-trench interactions in modern and ancient settings. Geological Society of America Special Paper 371: 1-18.

Somoza, R.; Ghidella, M.E. 2012. Late Cretaceous to recent plate motions in western South America revisited. Earth Planetary Science Letters 331-332: 152-163.
Stern, Ch.R. 2011. Subduction erosion: rates, mechanisms, and its role in arc-magmatism and the evolution of the continental crust and mantle. Gondwana Research 20: 284-308. doi: 10.1016/j.gr.2011.03.006.

Streckeisen, A. 1976. To each plutonic rock its proper name. Earth-science reviews 12: 1-33.

Suárez, M.; Emparán, C.; Muñoz, J. 1986. Geología de la parte oriental de la Hoja Curacautín, IX Región (Inédito). Servicio Nacional de Geología y Minería: 119 p. Santiago.

Suárez, M.; Emparán, C. 1997. Hoja Curacautín, Regiones de la Araucanía y del Biobío. Servicio Nacional de Geología y Minería. Carta Geológica de Chile 71: 105 p., 1 mapa 1:250.000. Santiago.

Sun, S.-S.; McDonough, W. 1989. Chemical and isotopic systematics of oceanic basalts: implications for mantle composition and processes. Geological Society London, Special Publications 42: 313-345.

Thomson, S.N.; Hervé, F. 2002. New time constraints for the age of metamorphism at the ancestral Pacific Gondwana margin of southern Chile (42-52 ${ }^{\circ} \mathrm{S}$ ). Revista Geológica de Chile 29 (2): 255-271. doi: 10.5027/andgeoV29n2-a07.

Thorkelson, D.J. 1996. Subduction of diverging plates and the principles of slab windows formation. Tectonophysics 255: 47-63.

Wall, R.; Lara, L. 2001. Lavas Las Pataguas: volcanismo alcalino en el antearco andino del Mioceno Inferior, Chile central. Revista Geológica de Chile 28 (2): 243-258. doi: 10.5027/andgeoV28n2-a06.

White, W. M. 2013. Geochemistry. Wiley-Blackwell: 668 p. Willner, A.P. 2005. Pressure-Temperature evolution of a late Palaeozoic paired metamorphic belt in North-Central Chile. Journal of Petrology 46: 18051833.

Manuscript received: April 18, 2017; revised/accepted: March 5, 2020; available online: September 30, 2020. 